\title{
O MERCADO DE MÄO-DE-OBRA VOLANTE NA AGRICULTURA PAULISTA, 1974/75 A 1986/87
}

\author{
MARIA CARLOTA MELONI VICENTE \\ Dissertação apresentada à Escola Superior de Agricultura \\ "Luiz de Queiroz", da Universidade de São Paulo, \\ para obtenção do titulo de Mestre em Agronomia. \\ Área de Concentração: Economia Agrária.
}

PIR A C I C A B A

Estado de São Paulo

1989 


\title{
O MERCADO DE MÃO-DE-OBRA VOLANTE NA AGRICULTURA PAULISTA, 1974/75 A 1986/87
}

\author{
MARIA CARLOTA MELONI VICENTE
}

Dissertação apresentada à Escola Superior de Agricultura "Luiz de Queiroz", da Universidade de São Paulo, para obtenção do título de Mestre em Agronomia. Área de Concentração: Economia Agrária.

\author{
PIRACICABA \\ Estado de São Paulo \\ 1989
}


Dissertaçāo apresentada à Escola Superior de Agricultura "Luiz de Queiróz", da Universidade de São Paulo, para obtençāo do thulo de Mestre em Agronomia, ărea de concentraçáo: Economia Agrána.

PIRACICABA

Estado de Sāo Paùo - Brasil

Fevereiro - 1989 
O MERCADO DE MAO-DE-OBRA VOLANTE NA AGRI CULTURA PAULISTA, 1974/75 a 1986/87

\section{MARIA CARLOTA MELONI VICENTE}

Aprovada em 09/05/1989

Comissão julgadora:

Prof. Dr. Evaristo Marzabal Neves

ESALQ/USP

Prof. Dr. Rodolfo Hoffmann

ESALQ/USP

Prof $\stackrel{a}{-} \quad$ Dr $\stackrel{a}{-}$ Rosa Ester Rossini

FFLCH/USP

Prof. Dr. Evaristo Marzabal Neves

Orientador 
Aos meus pais,

a Josē Roberto,

Alexandre e Carolina. 


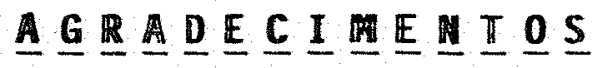

Agradecemos as seguintes pessoas e instituições

Ao Professor Dr. Evaristo Marzabal Neves, pela orientação na realização des te trabalho;

Aos Professores Dr. RodoTfo Hoffmann e Dr. Geraldo Sant'Ana de Camargo Barros, do Departamento de Economia e Sociologia Rural da ESALQ-USP, pelas criticas e sugestões apresentadas no projeto original e nas versoẽs preliminares que permitiram aperfeiçoar este trabalho;

$\bar{A}$ Professora Dra $\underline{\text { a }}$ Rosa Ester Rossini,doDepartamento de Geografia da FFLCH/USP, pelas críticas e suge'stões apresentadas;

Aos Pesquisadores Científicos Flāvio Condē de Carvalho e Afonso Negri Neto, do IEA,pe las sugestões e discussões iniciais;

Ao Pesquisador Científico Josē Roberto Vicente, pelas observações e comentārios;

As Colegas Elizabeth Alves e Nogueira e Celma da Silva Lago Baptistella, da Se ção de Estatĩsticas Söcio-Econômicas do IEA pelo estímulo, críticas e suges tões apresentadas no desenvolvimento desta dissertação;

Aos Pesquisadores Científicos Francisco Alberto Pino, Gabriel Luiz Seraphico Pei xoto da Silva, Ana Maria Montragio Pires de Camargo, Rosa Maria Pescarin Pe $]$. legrini, Abel Ciro Minniti Igreja e Denise Viani Caser pela colaboração em diversas fases da elaboração da pesquisa; 
$\bar{A}$ Professora Julie Ardenson, da Stanford University, pela sugestões;

A Elizabeth Madeira pela colaboração no processamento dos dados na fase inicial da pesquisa;

$\bar{A}$ Adnéa Ali Fakih e Nancy Carvalho Dioclécio pelo trabalho de datilografia;

Ao IEA, CNPq e EMBRAPA pe lo suporte oferecido durante o curso e em todas as fa ses desta pesquisa. 


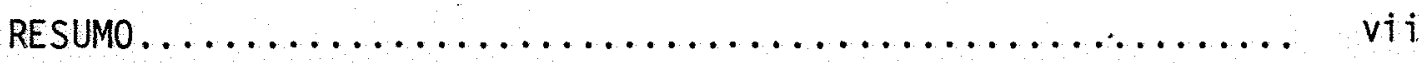

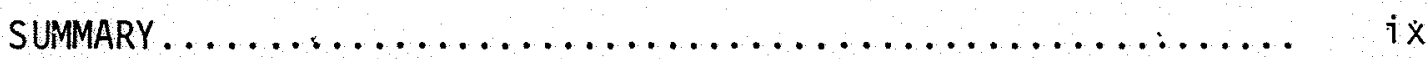

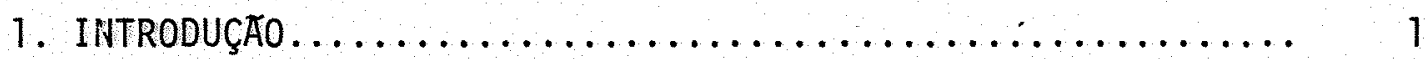

1.1. Aigumas caracteristicas do mercado de trabalho na agricultura paulista $\ldots \ldots \ldots \ldots \ldots \ldots \ldots \ldots \ldots \ldots$ 6

1.1.1. Trabalhadores volantes: conce i tuação e emprego 6

1.1.2. Evolução da produção, mecanização e uso da mão -de-obra nas principais culturas da agricultú ra paulista, $1974 / 75$ a $1986 / 87 \ldots \ldots \ldots \ldots \ldots .16$

2. METODOLOGIA.................................. 43

2.1. 0 mode10............................... 45

2.2. Cálculo das variāveis utilizadas nos modelos de ofer ta e demanda da mão-de-obra volante.............. 48

2.3. Fonte de dados........................... 53

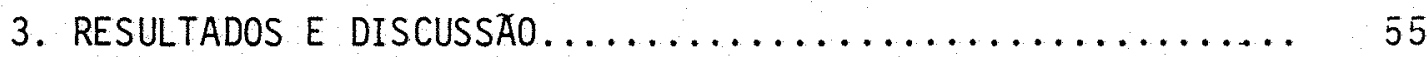

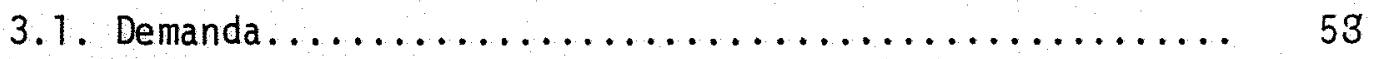

3.2. Oferta................................ 62

4. CONCLUSOES ................................. 65

REFERENCIAS BIBLIOGRAFICAS ....................... 63

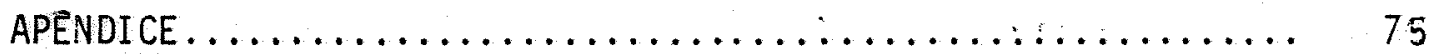


O MERCADO DE MAO-DE-OBRA VOLANTE NA AGRICULTURA PAULISTA, $1974 / 75$ A $1986 / 87$.

Autor: MARIA CARLOTA MELONI VICENTE Orientador: Evaris to Marzabal Neves

\section{RESUMO}

0 objetivo deste trabalho foi analisar aspectos da demanda e oferta de mão-de-obra volante na agricultura paulista.

0 mercado de mão-de-obra volante foi representado por equa ções simultāneas, onde as variāveis endógenas foram o nümero de volantes e o salārio. 0 período analisado estendeu-se de novembro de 1974 a setem bro de 1987, com observações para vārios meses do ano (fevereiro, abril, junho, setembro e novembro), o que possibilitou avaliar a estacionalidade do trabalho.

As estimativas dos parāmetros das equações estruturais fo ram obtidas pelo método dos Mínimos Quadrados em Dois Es tágios. Os dados bāsicos utilizados na pesquisa tiveram como fonte o Instituto de Economia Agricola e o Instituto Brasileiro de Geografia e Estatística.

Os resultados obtidos indicaram relativa inelasticidade-salārio da demanda e elasticidade -salārio da oferta da ordem de 1,03 . As variāveis deslocadoras da função de demanda foram a motomecanização das $\underline{o}$ perações de capina e colheita, a relação entre os preços recebidos e os preços pagos pelos agricultores, o emprego de residentes, a variävèl. bināria para o més de junho e a tendēncĩa.

$\mathrm{Na}$ equação de oferta foram significativos os coeficientes 
viii:

'das variāveis salārio da mão-de-obra volante, o salārio mínimo (utilizáa do como salärio alternativo) e a tendēncia. 
THE TEMPORARY (NONRESIDENT) AGRICULTURAL LABOR MARKET IN THE STATE OF SAO PAULO, BRAZIL, FROM $1974 / 75$ TO $1986 / 87$

Author: MARIA CARLOTA MELONI VICENTE Adviser: Prof. Evaristo Marzabal Neves

SUMMARY

The objetive of this research was to analyse aspects concerning to the demand for and the supply of temporary (nonresident) labor in the agriculture of São Paulo State, Brazil.

The temporary (nonresident) labor market was represented by a system of simultaneous equations where the endogenous variables were the number of temporary (nonresident) workers and the wage. The period analysed was from november of 1974 to september of 1987, and there were data for the months of february, april, june, september and november. This made it possible to es timate seazonal labor patterns.

The estimates of the parameters of the strutural equations were obtained by the Two Stage Least Squares method. The sources of the basic data utilized in this research were Instituto de Economia Agrícola (IEA) and Institu to Brasileiro de Geografia e Estatística (IBGE).

The results obtained showed that the demand was rather wage inelastic and that the wage elasticity of supply was about 1,03. Shift variables in the demand function were mechanization of cultivation and harvest operations, prices received by farmers relative to prices paid, the employment of resident workers, the dummy variable for the month of june and trend. 
In the supply equation the coefficients for the variables temporary (nonresident) wage, minimum wage determined by law (used as alternative wages). and trend were statistically significant. 
i. INTRODUÇÃO

Nas ūltimas trēs décadas, pesquísas sobre mão-de-obra na agricultura paulista têm relevado decréscimo no número de trabalhadores residentes na zona rural e crescimento do contigente dos chamados tra balhadores volantes (PAIVA, SCHATTAN e FREITAS, 1973) (VICENTE e BAPTIS TELLA, 1986).

Jā no final da década de trinta, CANABRAVA e MENDES (1938) citavam o deslocamento da população mais pobre das cidades da região de Piracicaba (SP) para a zona rural na época da safra e da colheita de al godão e de laranja.

BOMBO e BRUNELLI (1966) constataram que a Usina Monte A legre, localizada na região de Piracicaba,empregava, em 1945, cerca de quinhentos trabalhadores considerados volantes.

0 crescimento, no tempo, desta categoria de trabalhador ru ral encontra razões dentro do processo de desenvolvimento da agricultura paulista a partir dos anos cinquenta. Entre outras razões, cabe lembrar primeiramente as alterações observadas na estrutura de produção àgrīcola, com destaque para a introdução de māquinas, ocasionando uma diminuiçãa no uso de mão-de-obra. Por outro lado, em algumas épocas do ano o fator trabalho passa a ser demandado com maior intensidade.

Pode-se distinguir dois momentos qualitativamente distin tos na mecanização do ciclo de uma cultura. Inicialmente, ocorre a meca nização do preparo do solo, plantio e tratos 'culturais; essas 'opera f̧ões, por serem distribuĩdas por um período de tempo mais ou menos longo 
dentro do ano agrícola, eram realizadas pela mão-de-obrá residente na propriedade. A mecanização do preparo do solo, plantio e tratos cultu rais, transforma, portanto, mão-de-obra permanente em temporāria, ao reduzir o uso do fator trabalho nestas operaçōes. Na epōca de colheita das diversas culturas, o aumento da demanda por mão-de-obra é suprido por meio da contratação do trabalho temporārio.

A seguir, ocorre a mecanização da colheita e de suas atividades comple mentares (carregamento, transporte e beneficiamento). Neste caso, 0 correria principalmente, a substituição de mão-de-obra temporāria, de pendendo da relação entre o custo da māquina e o salārio pago por uni dade colhida (GRAZIANO DA SILVA, 1980).

Observa-se claramente a tendencia de se manter nas pro priedades rurais, apenas as famílias necessárias à realização de parte do processo produtivo, sendo o restante arregimentado fora da proprie dade, sempre que necessārio, com intenção de diminuir os custos com a mão-de-obra.

As mudanças na composição da produção agrícola presen. tes a partir da segunda metade dos anos sessenta, tambēm contribuiram para o crescimento da demanda por trabalho assalariado temporärio. So bre esse fato, ressalta-se significativo acréscimo da ārea cultivada com produtos de mercado externo, como a cana-de-açūcar e a Taranja,cul turas estas que devido às peculiaridades do processo produtivo, necessi tam do fator trabalho mais intensamente em algumas operações agríco. las.

Em resumo, a substituição de pastagens naturais e cultu彑 ras menos rentäveis por atividades mais lucrativas, foram acompanhadas por alterações na estrutura de produção decorrentes dos incentivos cria dos pelas políticas agrīcolas, em especial a do crédito subsidiado. 
Finalmente cabe lembrar a instituição do Estatuto do Trabalhador Rural (ETR) em 1963, equiparando os trabalhadores rurais aos urbanos. Muitos proprietārios, para fugirem às obrigações impostas pela nova legislação, passaram a utilizar os serviços de um único ho mem, o empreiteiro ou turmeiro, que se encarregava de uma determinada tarefa contratando trabalhadores por conta proppria.

Verificou-se que antes da institucionalização do Estatu to do Trabalhador Rural prevaleciam as contratações informais entre em empregado empregadọ. As especificaçōes contratuais bem como as $\underline{0}$ brigações e direitos das partes contratantes, normalmerüte não eram. fir madas por escrito. Apōs o Estatuto, os contratos passaram a ser fórma lizados estabelecendo as obrigações e direitos entre proprietārios e empregados. 0 sistema paternalístico anterior, de certa forma, cai por terra pois cabe ao empresärio conceder ao trabalhador e a sua famitia o que the for devido de acordo com as normas contratuais. 0 empregador tem que arcar com carteira de trabalho, férias, descanso semanal remunerado, décimo terceiro salārio e questões jurídicas, jun to aos seus empregados (PITERI, 1964).

Muitos proprietārios e mesmo uma grande parte dos tra balhadores rurais não vacilam emapontar as "leis" como responsāveis pe 10 aparecimento dos volantes (Sigaud, 1971 e Ferrante, 1976, citado por. GRAZIANO DA SILVA, 1980).

Ainda, segundo GRAZIANO DA SILVA (1980), mais importan te do que a questão cronológica do aparecimento do trabalhador volante, é a noção de que uma lei não pode criar uma relação de trabalho. Ao contrārio, ela procura apenas regulamentar a relação uma vez estabele 
cida. Assim é que o ETR, ao afetar a estabilidade dos empregados resi dentes tornou possivel liberar um grande contigente de mão-de-obra re tida nas antigas fazendas de café. Isso beneficiou particularmente os usineiros paulistas que empreendiam a expansão da cultura da cana-de-a çücar.

Nota-se portanto, que ao longo dos ültimos trinta anos um conjunto de fatores atuou para que a preferencia por trabalhadores volantes se acentuasse. Estes trabalhadores têm prestado serviços, nas mais diversas operações agrícolas, mas principalmente naquelas em que - uso de tração motomecânica não é praticada mais intensamènte por ra zões tēcnicas (topografia, tamanho da propriedade, māquinas não adapta das às nossas condições, etc), ou econömicas (altos investimentos e custos). Lembre-se, por exemplo, o plantio e a colheita de cana-de-açü car e as colheitas de algodão, café, laranja, amendoim e feijão.

Hā que se considerar ainda as condiçōes de trabatho a que se submete a mão-de-obra rural. Estudos têm mostrado que o volante trabalha em condições desfavorāveis quando comparado ao trabalhador ur bano. Evidenciam a existēncia de melhores oportunidades de trabalho no setor urbano, que se constitui num atrativo para estes trabalhadores, competindo com a realização das operações agrícolas.

Pesquisas que mostrem o surgimento desta categoria, suas causas e as mudanças nas relações de trabalho na agricultura, provenien tes da incorporação desta mão-de-obra no mercado de trabalho rural, bem como os ajustamentos na sua oferta e demanda, são importantes para a re solução de problemas presentes e futuros no mercado de mão-de-obra a grícola. 
Este trabalho pretende enfocar parte desses aspectos, principalmente os voltados para oferta e demanda da mão-de-obra vọ lante rural na agricultura paulista.

Para que se alcancem os objetivos propostos, o estudo es tarā dividido em quatro capj̄tulos.

Este capitulo considera ainda algumas características do mercado de trabalho no setor agrícola de São Paulo. Para maior com preensão, se subdivide em:

a) mão-de-obra volante em São Paulo: conceituação e em prego e

b) evolução da produção, mecanização e uso da mão-de-o bra nas principais culturas da agricultura paulista.

Pretende-se desta forma adicionar informações sobre o mercado de traba Tho rural e, em especial, o mercado de trabalho volante, mediante as al terações no processo produtivo, o que serā de grande valia na interpreta ção dos resultados das anälises subsequentes.

No segundo capítulo serā feita a apresentação dos modelos de demanda e oferta de mão-de-obra, dos dados utilizados e os procedi. mentos selecionados para mensuração das variāveis.

0 terceiro dedicarā atenção nạ anālise dos resultados das . equações de oferta e demanda do mercado de mão-de-obra volante.

Finalizando, no quarto capítulo, ē apresentado um resumo das conclusões dos capítulos anteriores.

O período de anālise compreenderā os anos agrícolas de 1974/75 a 1986/87, porque esse ê o período para o qual se dispõe das informações necessāriàs. 
1.1. Algumas Características do Mercado de Trabalho na Agricultura Pau lista

Este subcapítulo subdivide-se em duas partes:
a) trabalhadores volantes: conceituação e emprego
b) evolução da produção, mecanização e uso de mão-de-ọ bra nas principais culturas da Agricultura Paulista

\subsubsection{Trabalhadores Volantes: Concei tuação e Emprego}

As estimativas sobre emprego nos imōveis, efetuadas pe 10 Instituto de Economia Agrícola - IEA-em abril de 1975, revelavam ser de 1.321 mil o número de trabalhadores na agricultura Paulista. Desse total, 908 mil eram residentes no imōvel, 334 mi 1 volantes e $79 \mathrm{mi} 1$ ou tros não residentes.

Dentre os residentes, as categorias mais representativas eram os pro prietārios, parceiros, mensalistas e diaristas, com $84,0 \%$ do total, correspondendo o restante ao administrador, arrendatārio, empreiteiro, colono e outros.

Em 1979, a força de trabátho empregada nas atividades $\underline{a}$ grícolas passou a ser de $1.469 \mathrm{mil}$ trabalhadores, sendo $870 \mathrm{mil}$ resi dentes, 408 mi 1 volantes e 191 mil outros não residentes. Quanto à com posição da população trabalhadora residente nesse ano, proprietārios e seus familiares correspondiam a $42,0 \%$, mensalistas a $20,2 \%$, arrendatārios e parceiros $\bar{a} 14,1 \%$, diaristas a 7,8 e os $15,9 \%$ 
restantes englobavam administrador, empreiteiró, colono, e outros. De 1975 para 1979, as alterações mais significativas foram com relação ao nümero de parceiros, arrendatārios e diaristas, que decresceu en $35,0 \%$, enquanto que 0 número de mensalistas aumentou em $25,0 \%$.

Uma anālise comparativa entre as médias dos biēnios 1971-72, 1975-76 e 1979-80 demonstra que o contigente da mão-de-obra residente vinha. decrescendo à taxa de 7,1\% ao ano entre 1971-72 e 1975-76, passou a diminuir 2,0\% ao ano no período de 1975-76 a 1979-80, tendendo a se estabilizar em um mínimo necessārio de mão-de-obra rural permanente nas propriedades agrícolas. No que diz respeito à mão-de-o bra não residente, pode-se constatar um aumento relativo na sua utiliza ção, complementarmente ao contīnuo deciēscimo apresentado para a mãode-obra residente (PROGNOSTICO, 1980/81).

Em 1987, o levantamento efetuado pelo IEA em abril esti. mou em $1.527,9$ mi 1 o total de residentes e não residentes empregados nos imōveis rurais, detectando-se um acrēscimo de $4,0 \%$ com relação à 1979. O número médio diārio de volantes empregados foi estimado em 469,0 mil. Ainda em 1987, constatou-se que a mão-de-obra assalariada vi. nha ocupando o espaço de outras formas de relação de produção, ou seja, arrendatários e parceiros.

GRAZIANO DA SILVA (1980), ao analisar estimativas obtidas pe lo IEA, comenta que a partir de 1971 não se pode falar em tendéncia crescente do nümero de trabalhadores volantes ocupados na agricuitura paulista. 0 crescimento a partir dos anos setenta é somente relativo, ou seja, os volantes aumentam a sua participação relativa na força de trabalho empregada na agricultura,mostrando oscilações que se devem às 
variações sazonais da demanda.

Sobre tal observação pode se verificar que em 1970, os trabalhadores volantes, tambēm chamados de bōias-frias, safristas a ou trabalhadores não qualificiados constituiam $14,9 \%$ da força de trabaliho na agricultura.Em 1979 jā representavam 27,3\% e atualmente estima-se em $30,0 \%$ a sua participação (ano agrícola 1986/87).

Quanto ao conceito e características dos böias-frias, em um dos primeiros estudos realizados em Piracicaba, BOMBO e BRUNELLI (1966) utilizaram a seguinte definição: pessoas com empregos periōdi cos e relações de trabalho informais que vivem fora do estabelecimento rural em que trabalham habitualmente.

VASSIMON (1966) definiu-os como uma categoria de trabạ Thadores rurais, residentes na zona urbana, que exercem atividades a grícolas como diaristas em diversas propriedades, dependendo do merca do de trabalho.

ETTORI (1961) considerou volantes aqueles trabalhadores rurais que residem fora do estabelecimento rural,principalmente na zona urbana e vèm à propriedade para prestar serviços em determinadas épocas do ano. A remuneração dos mesmos é exclusivamente em dinheiro,e a mesma è estabelecida por dia ou tarefa executada. Observa também, que em geral, as diārias dos volantes são superiores àquelas recebidas pelos canara das permanentes da propriedade. São geralmente contratados em grupos, a travēs de entendimento direto entre o proprietārio e o chefe ou encarre gado da turma, o qual em certas regioões è denominado de "gato".

Para GONZALES E BASTOS (1975) o trabalho volante è uma modalidade de trabalho assalariado por tarefa, ou seja, uma forma con 
creta de relação social de produção capitalista. A natureza desta re lação pressupõe por um lado (não sō como condição necessāria, mas co mo resultado) um mínimo e sempre crescente volume de capital nas mãos dos empresārios agrícolas; e por outro lado, um contigente de trabalha dores despojados dos meios de produção.

A característica singular do trabalhador volante $\bar{e}$ que, apesar de ser um assalariado rural, tem o seu custo de reprodução de terminado ao nīvel do setor urbano. A disseminação do trabalhador vo lante na agricultura implica a união do mercaido de trabalho de toda a economia, com os benefícios que daí derivam para o capital (GRAZIAivo DA SILVA, 1982).

Observa-se que os conceitos citados caracterizam o tra balhador volante pela instabilidade de emprego e pela inexistencia de vínculo empregatício formal.

De acordo com BACCARIN (1985), quanto à instabilidade de emprego, encontram-se citaçōes na literatura de casos onde os volan tes apresentam vínculos mais permanentes com o proprietário, trabaînan do na mesma propriedade por períodos superiores a um ano, consti tuindo as chamadas turmas firmes. Verifica-se recentemente que a natureza temporāria e curta desses grupos de trabalho (volantes) não ē nem de longe tão generalizada como se pensava inicialmente. Numa sērie de ca sos verificou-se que o grupo de trabalho era de natureza bastante per manente e estāiel.

0 mesmo autor coloca o fato de que a instabilidade de trabaltho e a inexistência de vínculos formais de emprego são situações relacionadas. Pelo menos dois fatores têm importāncia na maior ou me 
nor instabilidade de emprego dos volantes. Um ē a prōpria sazonalida de das tarefas agrīcolas, pois à medida que as mesmas se tornam mais dispersas dentro do ano e de curta duração, ou seja, à medida que as necessidades de mão-de-obra por parte do empresärio sejam mais descon tínuas, a vinculação do volante tenderā a ser menor. Porēm, a inexis téncia de vínculo mais definitivo da mão-de-obra com a empresa pode trazer problemas nas épocas de maior necessidade como,por exemplo, as colheitas de cana-de-açūcar, algodão e laranja, que empregam grandes quantidades de trabalhadores.

0 crescimento da mão-de-obra volante na agricultura pau lista, na dēcada de setenta,-se deu principalmente a partir de 1976-77; no entanto, sua participação no total da força de trabalho é bastante importante desde o início do período (GARCIA, 1986). Esses trabalhado res têm sido empregados nas mais diversas operações agrícolas, princi palmente naquelas em que o uso de tração mecānica não é comum: as co Theitas de algodão, càfé, laranja, feijão, amendoim e arroz são alguns exemplos importantes. No caso da cana-de-açūcar é parcial a mecaniza ção das operações de plantio e colheita. Não ē mecanizada a colocação de toletes no solo e o corte da cana.

A demanda por volantes apresenta variações durante 0 ano, em consequência das diferentes atividades agropecuārias e mesmo de con dições climäticas que afetem o processo produtivo. As estimativas so bre dias-homens de trabalho volante utilizados nos meses do ano mostram que o emprego $\bar{e}$ intenso durante o ano todo, embora alguns meses sejam * mais importantes (VICENTE e BAPTISTELLA, 1987).

Considerando-se o período $1976-79$, nota-se claramente o 
crescimento do nümero de dias-homens nos meses de junho, jultho e agos to, quando se processammais intensamente as colheitas de cana-de-açūcar e café. 0 maior acrēscimo ocorreu em julho, com $3.838 \mathrm{mil}$ dias-homens em 1976 e 6.249 mil, em 1979. Isto significa maior nível de emprego mas, por outro lado, obriga os trabalhadores a constantes mudanças no esquema de trabalho, e inclusive ocasiona a vinda de pequenos agriculto res ou assalariados de outros estados (Tabela 1).

Em 1976, setembro, outubro, novembro e dezembro foram os meses de maior emprego (is to sem considerar janeiro, para o qual não hā estimativa), enquanto qué em 1977 o período de janeiro a março a presentou maior demanda. Nos meses de setembro, outubro e novembro são plantadas as culturas anuais, sendo que outubro concentra. o plantio das principais culturas anuais.

Feijão e amendoim das ã guas são colhidos no período de novembro a fevereiro. Em São Paulo, a colheita da laranja se estende praticamente durante o ano todo, havendo concentração em outubro, novem bro e dezembro, que representam pouco menos de $50 \%$ do total colhido no ano.

A produção de arroz começa a ser colhida em janeiro e as de algodão, mi tho e soja iniciam-se em fevereiro, 0 més de março con centra a colheita de algodão e soja, e o de abril a de milho. 0 plan tio de cana-de-açūcar de ano emeio é efetuado principalmente em feverei ro.

Em 1978 e 1979 destacam-se como os meses de maior emprega março, junho, jultho, outubro e novembro.

0 período de junho a agosto apresenta-se como o mais re 


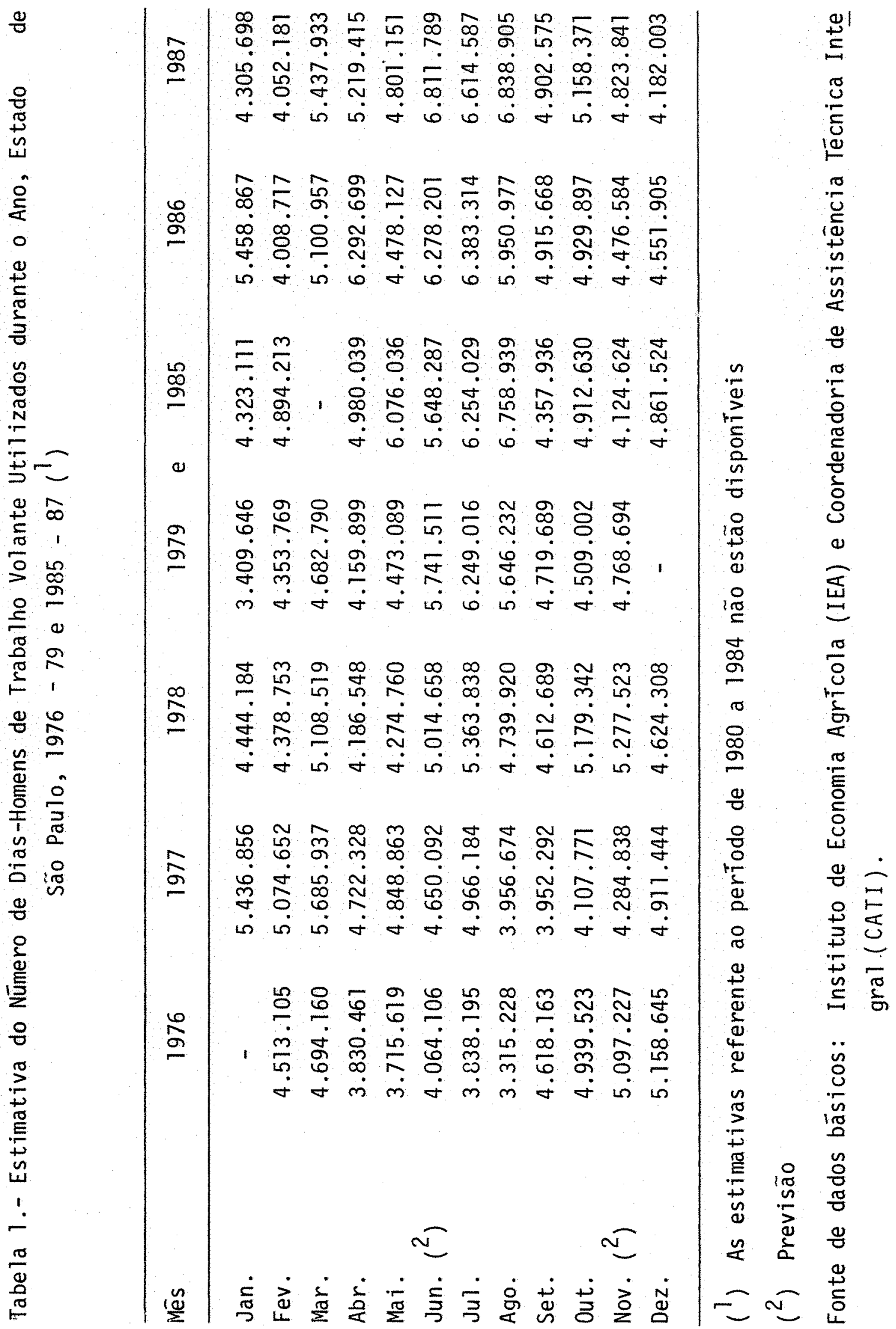


presentativo em meados da década de oi tenta, absorvendo $32,6 \%$ do tota 1 de dias-homens de trabalho volante em $1985,29,6 \%$ em 1986 , e $32,1 \%$ em 1987. São importantes tambēm abril e maio.

A utilização de mão-de-obräa volante vem, portanto, con centando-se nos meses de colheita de cana-de-açūcar, café e laranja e das culturas anuais. A necessidade desta mão-de-obra mais jntensa mente em alguns periodos, pode não ser suprida facilmente no tempo ne cessário. A cultura do algodão, por exemplo, possui na média . 56,08\% da ārea colhida em março,22,06\% em abril e 16,13\% em fevereiro (NOJI Мото, 1987).

- Estes são meses de colheita de outras culturas anuais, de plantio de cana-de-açūcar, e o algodão precisa ser colhido nesse pe rĩodo para reduzir perdas. Aliās,este $\bar{e}$ um dos fatores que limita o cultivo de grandes āreas.

Sabe-se tambëm, que o trabalhador volante mui tas vezes, faz parte ora da força de trabalho rural, ora da força de trabalho ur bano.

Segundo QUEDA et alii (1977), nos estudos de caso atē então realizados, são poucas as referéncias a respeito da absorção dos trabalhadores volantes pelos setor urbano nas épocas de entressafra.

Os autores citam SANTOS (1975) que, em trabalho pionei ro sobre o assunto, estudou a aceitação do trabalhador volante por par te do setor industrial da cidade de Votuporanga, è encontrou que: a) a metade das indūstrias pequenas, dois terços das médias e a totalidade das grandes jā havia tido alguma experiēncia em relação ao emprego de trabalhadores volantes, b) apenas $15 \%$ das indūstrias pequenas e $25 \%$ das 
médias aceitaria contratar trabalhadores volantes. Jā a totalidade das grandes mostrava-se disposta a tal empreendimento.

BRANDT (1977), num levantamento na região de Assis, afirma que "a situação mais comum parece ser a de alternativa de em pregos temporärios urbanos e rurais, seja do trabalhador individual, seja de membros da familitia. Os empregos urbanos, nesse caso, são os de servente' de pedreiro para os homens e o de doméstica ou lavadei ra para as mutheres na maioria dos casos".

D'INCAO e MELLO (1975) salienta que as atividades e xercidas pelo böia-fria, fora das ēpocas de colheita, são mui to va riadas. Dos 50 entrevistados, $43,5 \%$ frequentemente não realizavam outro tipo de trabalho,e dentre os que trabalhavam,10,5\% geralmente desempenhavam a função de serventes de pedreiros, $15,2 \%$ são diaris tas no meio rural,e os demais se distribuem em outras funções (todos do sexo masculino).

SILVA e FREITAS (1976) encontraram 32\% dos entrevista dos que declararam trabalhar o ano todo como bōia-fri.a, na DIRA de Sorocaba.

BACCARIN (1985), analisando a região de Jaboticabal, mostra que durante as safras de laranja e cana-de-açūcar o mercado de trabatho volante apresenta maior estabilidade e formalidade dos contratos de trabalho, o mesmo não ocorre no período de entressafra, pois os serviços passam a ser mais variados, de curta duração e ins tāveis. De 50 trabalhadores entrevistados sobre as atividades no período de entressafra de cana e laranja, em relação à ocupação da safra, observa-se que $21,5 \%$ das atividades referidas foram no se 
tor urbano, especialmente na construção civil.

Mesmo sem uma constatação a nĩvel do estado de São Paú 10, mas apenas indicações de algumas regiões, os estudos mencionados mostram a participação eventủal de parte da mão-de-obra volante no mercado de trabalho urbano. Em 1986, por exemplo, ano de introdução do Plano Cruzado, a competição do mercada urbano pela mão-de-obra rú ral foi focalizada em reportagem que afirmava: "A falta de gente pa ra trabalhar no campo se confirma em muitos estados brasileiros, do ponto de vista do empresārio rural. Do ponto de vista do trabalhador, a oferta de mão-de-obra ē grande, mas os salārios oferecidos não com pensam, daí o exōdo para as cidades, que experimentam uma efervescên cia econōmica. 0 setor da construção civil sempre foi apontado pe los produtores, como o grande concorrente pela mão-de-obra não especią lizada" (Folha de São PauTo, 04/11/86, Suplementa AGROFOLHA, p.8).

Cabe salientar também que as conquistas obtidas pelo trabalhador rural na Nova Constituição, relacionadas à igualdade de di reitos entre os trabalhadorescom vinculo empregaticio permanente e 0 trabalhador avulso, poderão ocasionar altèräções no processo produtivo agrícola e nas relações de trabalho, razão pela qual os estudos sobre mercado de trabalho agrícola poderão fornecer subsídios para resolução de problemas que estão ocorrendo e de outros que, provavelmente, i rào acontecer. 
1.1.2. Evolução da Produção, Mecanização e Uso da Mão-de-Obra nas Princi. pais Culturas da Agricultura Paulista, 1974/75 a 1986/87

Alguns estudos foram realizados com a finalidade de ana lisar as alterações ocorridas na agricultura paulista, nos anos seten ta, e as consequéncias na utilização de mão-de-obra.

GATTI (1984) quantificou o processo de mudanças na com posição da produção nas diversas Divisões Regionais Agrīcolas (DIRAs) do Estado, em termos de ārea ocupada pelas diversas atividades agrope cuārias. O autor procura verificar aquelas que se expandiram easquese retraíram nesse processo, as que substituiram e as que foram substituí. das, avaliando os efeitos dessas alterações sobre a utilização de mãode-obra pelo setor, em termos dé nīvel, composição do emprego e padrão de ocupação durante 0 ano agrícola (sazonalidade). Os produtos agríco las considerados foram: a lgodão, amendoim das āguas, amendoim da seca , arroz, batata das àguas, Batata da seca, batata de inverno, fei.jão das āguas, feijão da seca, feijão de inverno, mamona, mandioca, mi tho, so ja, tomate envarado, tomate rasteiro, trigo, cebola, chā, banana, uva comum de mesa, uva para indūstria, Taranja, café, cana-de-açūcar, pecuā ria de corte e pecuäria de leite. Por inexistencia de dados, não fo ram consideradas as atividades hortifrutigranjeiras.

Os resultados da pesquisa, rela,tivos à composição da produ çâo agrícola paulista, apontaram no período 1968/70 a 1980/82, uma re tração de $7,13 \%$ na ārea cultivada com os produtos acima citados. Eśse comportamento significou uma destinação de 1,2 mi hhão de hectares para 
outras ocupações (silvicultura, horticultura, reserva de valor, chāca ras de Tazer, perdas por urbanização e erosão, etc.), e também uma re composição da produção, com expansão de algumas atividades em detrimen to de outras.

Salienta o autor que do total de 2,3 milhões de hecta res de ārea expandida por culturas pertencentes ao sistema considerado, $40,51 \%$ destinaram-se à cana-de-açūcar, 19,32\% à soja, 15,77\% à laranja, $8,17 \%$ ao café, $7,78 \%$ às āreas com pastagens formadas e $6,22 \%$ ao feijão das āguas. Desse tota 1, 61,08\% eram provenientes da ārea ocupada an teriormente por pastagens naturais, $12,28 \%$ por arroz, $10,62 \%$ por algo. dão, 6,07\% por mi tho, 2,05\% pormandioca e 1,73\% por mamona.

Tomando-se apenas o período 1974/76 a 1980/82, a expan são de cerca de 1,1 mi 1hão de hectareș com as ațividades cana-de-açūcar $(56,37 \%)$, laranja $(12,42 \%)$, feijão $(11,39 \%)$, soja $(8,63 \%)$ e café $(8,07 \%)$ se fez em detrimento, principalmente, das āreas de pastagens (naturais e formadas) e de arroz.

Os resultados encontrados com relação à mão-de-obra', es timada em termos de mil dias-homens de trabalho, indicam um crescimento do nível de utilização de cerca de $3,21 \%$ no período 1968/70 a 1980/82. Ao subdividir o período, a utilização de mão-de-obra decresce $7,28 \%$ en tre 1968/70 e 1974/76, e crésce entre $1974 / 76$ e 1980/82. Salienta que as culturas que se expandiram no subperíodo 1968/70 a 1974/76 o fize ram, basicamente, em detrimento de āreas ocupadas com atividades agrí colas - algodão, amendoim, arroz, mandioca e mamona; que utilizam con sideravelmente o fator trabalho. No subperiodo de 1974/76 a 1980/82, as expansões se deram atravēs da incorporação de āreas com pastagens, 
18.

de menor absorção de mão-de-obra,e de āreas cultivadas com arroz.

VICENTE (1985) analisou estimativas dos anos agrícolas 1974/75, 1975/76 e 1979/80, sobre o nümero de dias-homens nas opera ções de preparo do solo, adubação, plantio, tratos culturais e colhei ta, obtidas por meio da amostra utilizada pelo IEA, para estimar a pro dução das principais culturas da agricultura paulista. Os resultados mostraram que das nove culturas estudadas (al godão, amendoim, arroz, feijão, mitho, soja, cana-de-açūcar, café e laranja), café é aquela que mais emprega o fator trabalho. Notou-se também o crescimento da participação relativa das culturas de cana-de-açūcar, laranja e feijão na utilização de mão-de-obra, face à expansão destas culturas no esta do, enquanto que decréscimos foram observados para algodão, amendoim, arroz e mitho. A comparação de 1979/80 e 1975/76 mostrou queda no nú mero de dias homens utilizados.

GHILARDI (1987) analisou, para quatro tamanhos de pro priedades e com base nas atividades que absorvem as maiores parcelas de āreas na agricultura paulista, a evolução da composição da produção, a importancia das propriedades na quantidade produzida, o uso de insu mos quĩmicos e a utilização de mão-de-obra, animal e māquinas.Utilizou dados dos anos agricolas 1970/71 a 1972/73 e 1977/78 a 1979/80. As pro priedades, classificadas com base na ārea total, foram denominadas de mini $(3,1$ a 20 , Oha), pequena $(20,1$ a 100 , Oha $)$, média $(100,1$ a 500 , 0ha) e grande (acima de 500,0ha). No tocante à utilização de mão-de-obra,o autor considerou as seguintes culturas: algodão, amendoim, arroz, mi Tho, café, cana, feijão, laranja e soja. As estimativas referem-se as médias calculadas para os anos agrícolas 1970/71 - 1972/73 e 
1977/78 - 1979/80. Verifica-se que, entre o início e o final da década de setenta, a utilização de trabalho no Estado de São Paulo apresenta redução de $6,25 \%$, caindo o total de dias trabalhados de 118,1 milhões para 110,7 mi ihões de dias. Em todos os tamanhos de propriedades, 0 uso de trabalho situava-se em nivel inferior ao do início do período, tendo ocorrido variação maior nas propriedades com ärea total de atē 100,0ha. Quanto à recomposição da produção, um grupo de atividades (ca na-de-açūcar, café, feijão das āguas, laranja, soja e pastagem formada) expandiu sua participação na ārea de todos os tamanhos de propriedade, em detrimento da participação de outro agrupamento (algodão, amendoim das àguas, arroz, mi tho e pastagem natura1). Nas culturas cujas āreas cultivadas se reduziram na década de setenta, foram verificadas acentua das quedas nos dias trabalhados para todos os tamanhos de propriedade. Nas culturas com expansão de ārea, que jā no início do período contavam com elevada participação de técnicas modernas, observaram, em todos os tamanhos de propriedades, expressivos aumentos nos dias trabalhados.

As pesquisas citadas mostram o crescimento, na década de setenta, das āreas com cana-de-açūcar, laranja, café e soja, em àa reas antes ocupadas principalmente por pastagens naturais. Evidenciam tambēm a crescente utilização do fator trabalho na cana-de-açūcar, la ranja e café, decorrente da expansão dessas culturas.

Tomando-se agora os anos agrícolas de 1985/86 em rela ção a 1979/80, observa-se que cana-de-açücar e laranja continuam em ex pansão, sendo que a àrea com cana para indūstria, que era de $1.290,00$ mi 1 hectares em $1979 / 80$, passa para $2.031,10$ mil hectares (acréscimo de $57,4 \%$ ) em $1985 / 86$, enquanto que na cultura da Taranja a ārea passa de 
$532,90 \mathrm{mil}$ hectares para $677,90 \mathrm{mil}$ hectares (aumento de $27,2 \%$ ). Jā a produção da cana cresce em $73 \%$ (de 71.050 mil toneladas em 1979/80 pa ra 122.910 mil toneladas em 1985/86) e a delaranja 16,2\% (passando de $6.671,70$ mil toneladas para $7.754,90$ mil toneladas no mesmo período) . Deve-se salientar, que $1985 / 86$ foi um ano atípico devido $\bar{a}$ seca, que prejudicou a produção das culturas perenes e semi-perenes com maior intensidade.

Algodão, arroz, milho, trigo e mandioca também apresenta ram crescimento na ārea cultivada, quando se compara 1979/80 e 1985/86, e a produção destas culturas foi também superior em 1985/86 a pesar da seca ocorrida no inicio da safra. Decréscimos de ārea foram constatados para soja $(-16,5 \%)$, café $(-18,8 \%)$, amendoim das àquas $(-32,7 \%)$, amendoim da seca $(-44,2 \%)$ e mamona $(-28,4 \%)$. Na safra pos terior (1986/87) ocorre retração nas āreas de algodão $(-1,3 \%), \quad$ arroz $(-11,4 \%)$, trigo $(-15,0 \%)$, mandioca $(-16,1 \%)$, amendoim das àguas $(-3,4 \%)$, e amendoim da seca $(-34,3 \%)$ e crescimento na ārea com milho $(14,4 \%)$ (Tabela 2).

Permanece portanto, ainda em meados da década de oiten ta, a expansão da cana-de-açūcar e da laranja.

No tocante à utilização de mão-de-obra nas principais culturas (ano agrícola 1974/75), resultados obtidos do levantamento "Me dição da Técnica Empregada", efetuado juntamente com o levantamento de previsões e estimativas de safras do IEA, revelam que o café absorveu 


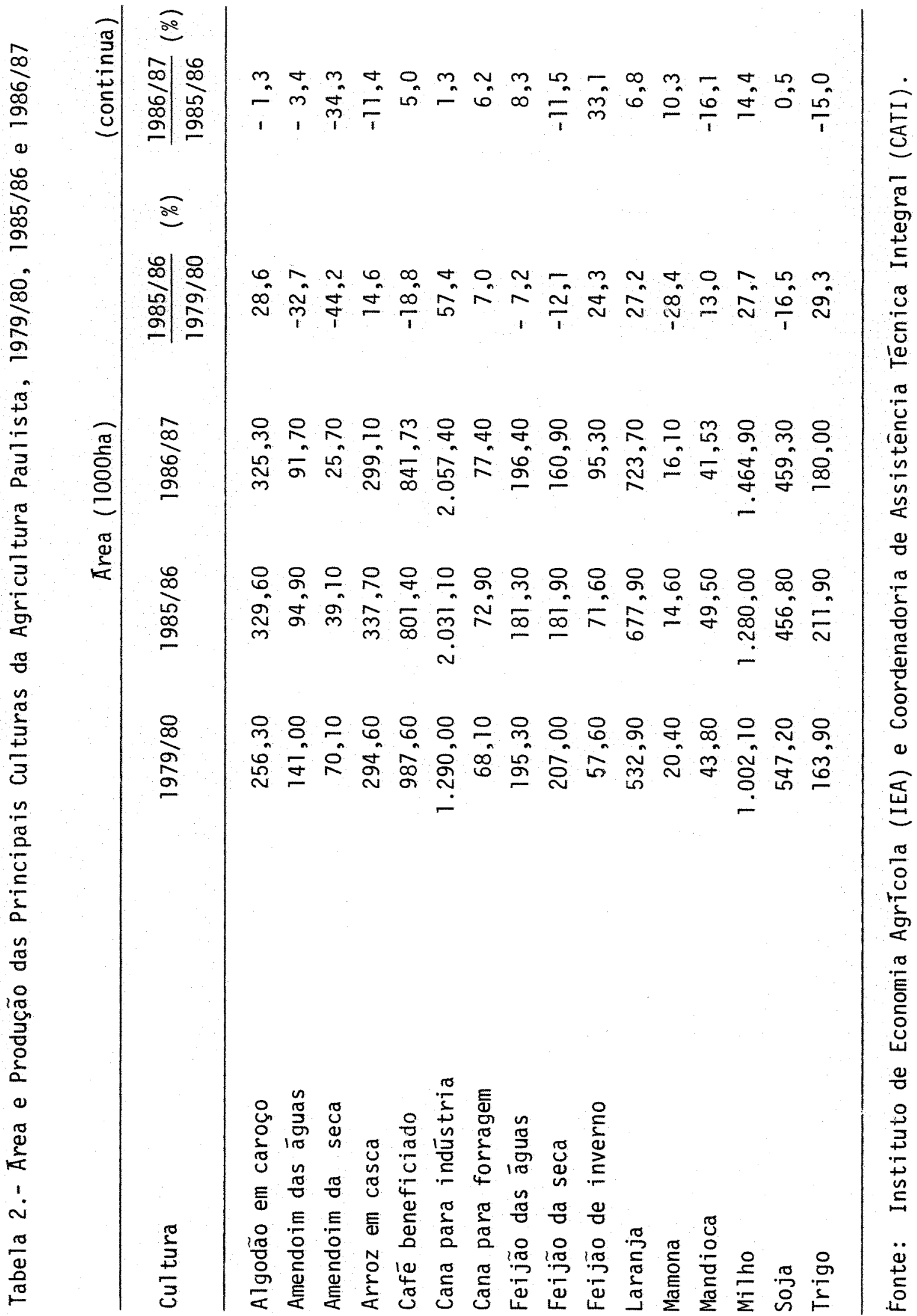




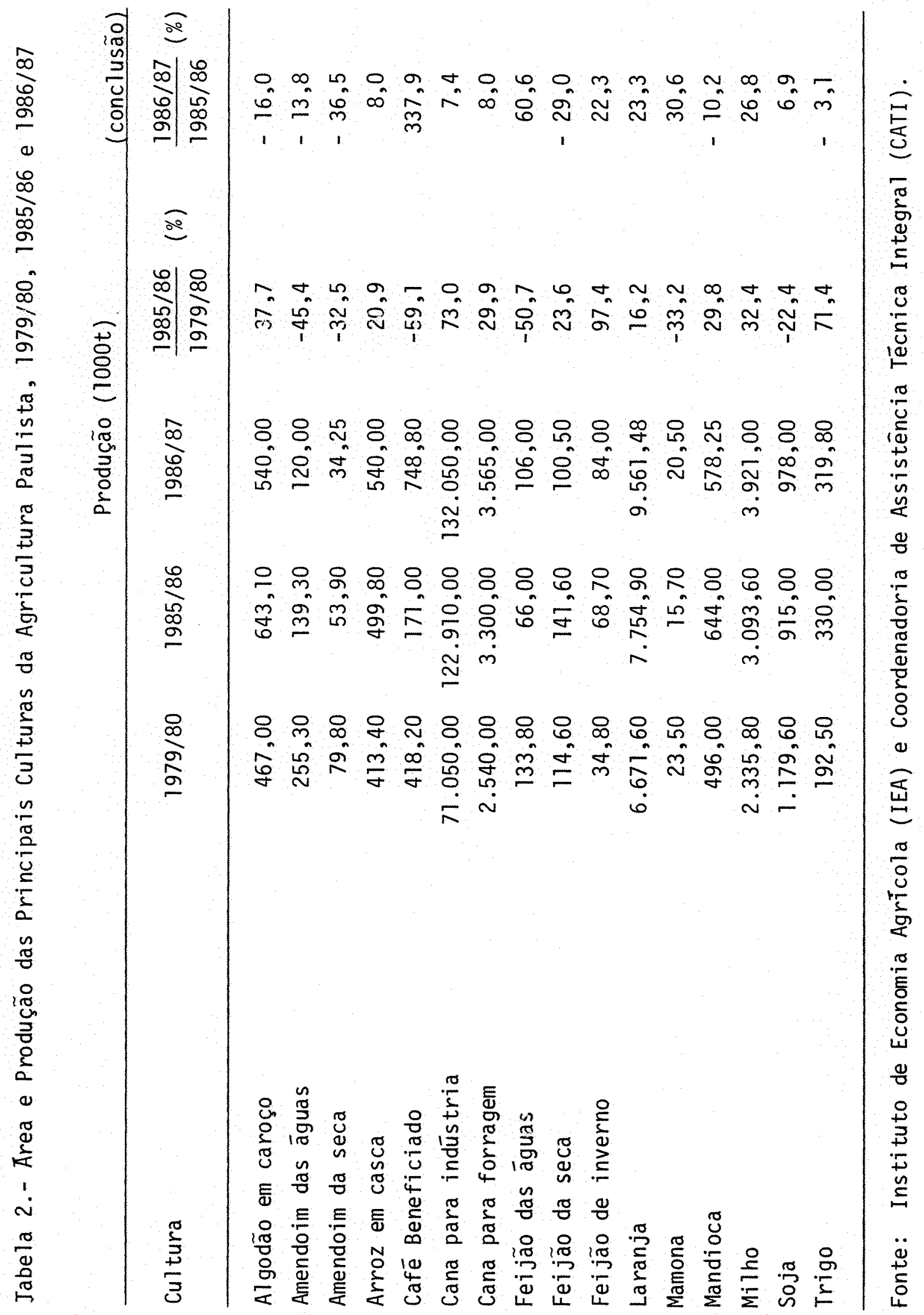


$46,7 \%$ do total de dias-homens utilizados em nove culturas $\left({ }^{1}\right)$. Jà em $1975 / 76$, quando à produção de café decresceu $23,4 \%$, esse percentual caiu para $37,3 \%$, passando a $48,2 \%$ em $1979 / 80$. Em meados da década dé oitenta,o café ainda liderava a utilização do fator trabalho; apresen tando participação menor de acordo com a produção ob́tida (Tabela 3 ).

A participação da cana-de-açūcar e da laranja, nó total de dias-homens utilizados vem aumentando, enquanto que algodão, amen doim, arroz e milho tem apresentado uma retração. Considerando-se que a cana-de-açūcar ea laranja apresentaram significativos acrēscimos na produção, e por serem explorações agrīcolas cuja colheita é em grànde parte efetuada pelo processo manual, é de se supor uma maior demanda por mão-de-obra para essas culturas. O feijão tambēm aumentou a par ticipação no total de mão-de-obra utilizada pelas nove culturas.

Com relação ao emprego de mão-de-obra nas diversas ope rações agrícolas (preparo do terreno, plantio e adubação, adubação em cobertura, tratos culturais e colheita) observa-se o crescimento da participação relativa da operação de colheita, de 1974/75 para 1986/87. Embora existam variações entre os anos apresentados, pode-se notar es sa tendēncia.. A participação da colheita é menor em anos atīpicos,

(1)

Efetuado para: algodão, amendoim, arroz, feijão, milho, soja, ca na-de-açücar, cafè e laranja. 
Tabela 3.- Distribuição Relativa do Nümero de Dias-Homens Utilizados em Culturas ( ${ }^{1}$ ) do Estado de São Paulo, 1974/75, 1975/76, $1970 / 80,1985 / 86$ e $1986 / 87\left({ }^{2}\right)$

(em percentagem)

\begin{tabular}{lrrrrr} 
Cultura & $1974 / 75$ & $1975 / 76$ & $1979 / 80$ & $1985 / 86$ & $1986 / 87$ \\
\hline Algodão & 12,8 & 7,9 & 7,2 & 11,6 & 7,3 \\
Amendoim & 3,7 & 5,3 & 2,9 & 2,1 & 1,1 \\
Arroz & 8,8 & 11,5 & 4,7 & 4,9 & 2,5 \\
Feijão & 2,1 & 3,5 & 3,0 & 3,7 & 4,1 \\
Milho & 12,5 & 16,8 & 10,1 & 9,4 & 7,5 \\
Soja & 0,5 & 0,7 & 0,5 & 1,0 & 0,5 \\
Cana de açūcar & 9,1 & 12,3 & 14,2 & 22,1 & 28,6 \\
Café ( $\left.{ }^{3}\right)$ & 46,7 & 37,3 & 48,2 & 33,6 & 38,7 \\
Laranja ${ }^{3}$ ) & 3,8 & 4,7 & 9,2 & 11,6 & 9,7 \\
Total & 100,0 & 100,0 & 100,0 & 100,0 & 100,0
\end{tabular}

(') Nas operações de: preparo do solo, adubação e plantio, tratos cul turais e colheita.

$\left(^{2}\right)$ Em 1987, o levantamento dos dados foi efetuado em setembro e no vembro, com a finalidade de se obter uma estimativa mais correta da mão-de-obra na cana-de-açúcar e laranja: Nos anos anteriores o levantamento era efetuado em junho.

${ }^{3}$ ) Em 1974/75, 1975/76, 1979/80 e 1985/86, somente nas operações de: adubação, tratos culturais e colheita.

Fonte dos dados bāsicos: Instituto de Economia Agrícola (IEA) e Coor denadoria de Assistência Técnica Integral (CATI). 
quando a produção de diversas culturas ē menor,principalmente a do café. 0 percentual da operação preparo do terreno, considerando-se o somatō rio das nove culturas, era de $5,3 \%$, em $1974 / 75$, atingindo $3,8 \%$ em 1986/87,e plantio e adubação que correspondiam a $8,2 \%$ passam a $\quad 5,8 \%$ (Tabela 4).

Considerāvel decréscimo foi constatado para tratos culturais, ou seja, de $43,5 \%$ para $25,4 \%$, de meados da década de seten ta para 1986/87. Essa tendéncïa ocorreu nas nove cultüras, com maior intensidade na cana-de-açūcar e com menor no feijão.

Saliente-se tambëm, que:em 1985/86, tem se maior utili zação de mão-de-obra no preparo do terreno, plantio a adubação. das culturas anuais em comparação aos outros ános, devido à seca ocorrida no inf̧cio da safra, que desorganizou à produção. Houve a necessidade de replantio de lavoüras. A seca afetou seriamente a produção de fej jão e cafê, prejudicando tambēm a cana-de-açūcar e laranja, ocasionan. do menor participação da operação de colheita em relação às outras $\underline{0}$ perações.

A diminuição do uso do fator trabatho nas diferentes 0 perações estā relacionado, principalmente, à intensificação do uso de tração motomecānica. Apresenta-se a seguir algumas discussões sobrëa relação māquina e măo-de-obra.

Os principais reflexos da motomecanização na produção agrïcola podem ser observados através do aumento da produtividade, do trabalho e na possibilidade de se ampliar a utilização de präticas a gronómicas que aumentem o rendimento das culturas. A intensificação da mecanização depende em larga escalà de fatores económicos. 
26.

Tabela 4.- Distribuição Relativa do Número de Dias-Homens Utilizados em Nove Culturas do Estado de São Paulo, Por Operação Agrí cola, 1974/75, 1975/76, 1985/86 e 1986/87

\begin{tabular}{|c|c|c|c|c|}
\hline \multirow[b]{2}{*}{ Algodão } & \multicolumn{3}{|c|}{ (em percentagem) } & \multirow{2}{*}{$\frac{(\text { continua) }}{1986 / 87}$} \\
\hline & $1974 / 75$ & $1975 / 76$ & $1985 / 86$ & \\
\hline Preparo do terreno & 4,5 & 4,0 & 4,2 & 5,5 \\
\hline Plantio e adubação & 3,8 & 4,2 & 5,7 & 2,3 \\
\hline Adubação em cobertura & - & - & 3,4 & 1,7 \\
\hline Tratos culturais & 28,3 & 27,5 & 11,3 & 16,5 \\
\hline Colheita & 63,4 & 64,3 & 75,4 & 74,0 \\
\hline Amendoim & $1974 / 75$ & $1975 / 76$ & $1985 / 86$ & $1986 / 87$ \\
\hline Preparo do terreno & 8,5 & 9,7 & 21,2 & 7,1 \\
\hline Plantio e adubação & 6,4 & 6,2 & 6,2 & 4,8 \\
\hline Adubação em cobertura & - & - & 0,1 & 9,6 \\
\hline Tratos culturais & 35,4 & 29,0 & 18,1 & 24,4 \\
\hline Colheita & 49,7 & 55,1 & 54,3 & 62,6 \\
\hline Arroz & $1974 / 75$ & $1975 / 76$ & $1985 / 86$ & $1986 / 87$ \\
\hline Preparo do terreno & 12,7 & 11,7 & 20,7 & 16,9 \\
\hline Plantio e adubação & 2,1 & 2,1 & 15,2 & 10,7 \\
\hline Adubação em cobertura & 8,3 & 9,8 & 2,5 & 2,2 \\
\hline Tratos culturais & 45,8 & 41,7 & 29,9 & 36,2 \\
\hline Colheita & 31,1 & 34,7 & 31,7 & 34,0 \\
\hline Feijão & $1974 / 75$ & $1975 / 76$ & $1985 / 86$ & $1986 / 87$ \\
\hline Preparo do terreno & 18,1 & 17,6 & 20,1 & 13,1 \\
\hline Plantio e adubação & 14,8 & 15,6 & 11,6 & 9,6 \\
\hline Adubação em cobertura & - & - & 4,7 & 2,4 \\
\hline Tratos culturais & 34,8 & 32,3 & 25,0 & 33,8 \\
\hline Colheita & 32,3 & 34,5 & 38,6 & 41,1 \\
\hline
\end{tabular}


Tabela 4.- Distribuição Relativa do Número de Dias-Homens Utilizados em Nove Culturas do Estado de São Paulo, por Operação Agrī cola, 1974/75, 1975/76,1985/86, 1986/87

(em percentagem)

\begin{tabular}{lcccc} 
& & (em percentagem) & (continua) \\
\hline Milho & $1974 / 75$ & $1975 / 76$ & $1985 / 86$ & $1986 / 87$ \\
\hline Preparo do terreno & 15,4 & 15,4 & 18,7 & 19,1 \\
Plantio e adubação & 13,2 & 14,2 & 11,3 & 12,6 \\
Adubação em cobertura & - & - & 6,2 & 5,7 \\
Tratos culturais & 33,5 & 30,6 & 22,1 & 24,4 \\
Colheita & 37,9 & 39,8 & 41,7 & 38,2 \\
\hline & & & & \\
\hline Soja & $1974 / 75$ & $1975 / 76$ & $1985 / 86$ & $1986 / 87$ \\
\hline Preparo do terreno & 31,9 & 21,0 & 22,8 & 37,0 \\
Plantio e adubação & 11,8 & 15,6 & 14,0 & 17,4 \\
Adubação em cobertura & - & - & 1,7 & 2,2 \\
Tratos culturais & 44,0 & 49,5 & 37,5 & 30,0 \\
Colheita & 12,3 & 13,9 & 24,0 & 13,4 \\
\hline
\end{tabular}

\begin{tabular}{lcccc}
\hline Cana de Açúcar & $1974 / 75$ & $1975 / 76$ & $1985 / 86$ & $1986 / 87$ \\
\hline Preparo do terreno & 6,5 & 4,0 & 2,1 & 2,3 \\
Plantio e adubação & 15,2 & 17,6 & 7,7 & 11,5 \\
Adubação em cobertura & - & - & 2,1 & 1,8 \\
Tratos culturais & 33,3 & 34,3 & 11,0 & 7,8 \\
Colheita & 45,0 & 44,1 & 77,1 & 76,6 \\
\hline & & & & \\
\hline Café & $1974 / 75$ & $1975 / 76$ & $1985 / 86$ & $1986 / 87$ \\
\hline Preparo do terreno & - & - & - & 0,5 \\
Plantio e adubação & - & - & - & 1,5 \\
Adubação em cobertura & 6,2 & 6,8 & 5,7 & 4,0 \\
Tratos culturais & 52,0 & 66,8 & 47,9 & 36,0 \\
Colheita & 41,8 & 26,4 & 46,4 & 58,0 \\
\hline
\end{tabular}


Tabela 4.- Distribuição Relativa do Número de Dias-Homens Utilizados em Nove Culturas do Estado de São Paulo, por Operação Agrícola, $1974 / 75,1975 / 76,1985 / 86,1986 / 87$

(em percentagem)

\begin{tabular}{lcccc}
\hline Laranja & $1974 / 75$ & $1975 / 76$ & $1985 / 86$ & $1986 / 87$ \\
\hline Preparo do terreno & - & - & - & 0,6 \\
Plantio e adubação & - & - & - & 1,3 \\
Adubação em cobertura & 6,3 & 10,0 & 5,8 & 3,3 \\
Tratos cul turais & 43,9 & 48,8 & 42,9 & 36,1 \\
Colheita & 49,8 & 41,2 & 51,3 & 58,7 \\
\hline & & & & \\
\hline TOTAL & $1974 / 75$ & $1975 / 76$ & $1985 / 86$ & $1986 / 87$ \\
\hline Preparo do terreno & 5,3 & 6,3 & 5,5 & 3,8 \\
Plantio e adubação & 8,2 & 10,7 & 5,3 & 5,8 \\
Adubação em cobertura & - & - & 4,4 & 3,2 \\
Tratos culturais & 43,0 & 44,3 & 30,5 & 25,4 \\
Colheita & 43,5 & 38,7 & 54,3 & 61,8 \\
\hline
\end{tabular}

Fonte dos dados bäsicos: Instituto de Economia Agrícola (IEA) e Coorde nadoria de Assistēncia Técnica Integral (CATI) 
"Evidencias empíricas relacionadas ao éfeito de altera ções na relação de preços dos fatores sobre a relação de emprego dos mesmos são apresentadas, por exemp 10, por SANDERS (1973), BATISTA (1976) e LOPES e SCHUH ( 1979). E interessante observar que evidēn cias claras a respeito da suḅstituição entre tratores e mão-de-obra tendem a provir de anālises de dados de cortes-seccionais no tempo . Anālises de sēries temporais quando resultam em coeficientes signifi cativos estatisticamente, apontam para a complementariedade" (BARROS, 1980 , p. 30).

No caso de cortes-seccionais no tempo, resultados da pesquisa efetuada por Lopes e Schuh para diversos estados do Paîs em 1963/64 e 1972/73 favorecem a hipótese de que a elasticidade substitui ção seja inferior a unidade, indicando que variaçōes na relação salā rio-preço do trator acarretariam variações menos que proporcionais ná relação trator - mão-de-obra. SANDERS obteve estimativas da elastici dade de substituição inferior à unidade para o Estado de São Paulo em 1960, o que leva a crer que relativamente pouco da variação na relação trator - mão-de-obra ocorrida no Estado de São Paulo, de 1960 a 1970 , era explicada pela distorção nos preços relativos (BARROS, 1980).

BATISTA (1976) analisou o período de 1950 a 1974, pa ra a região Centro-Sul, encontrando evidéncias de que não estā havendo na região uma relação de substituição entre mão-de-obra e tratores a grícolas, e SANDERS (1973) não obteve coeficientes significativos para os efeitos de salārios e preços na função de investimento em tratores agrícolas, para o período de 1950 a 1971. 
Quanto a evolução do.processo de mecanização no Estado de São Paulo, de acordo com GHILARDI (1987), entre janeiro de 1973 e a bril de 1979 , houve um crescimento relativo de $88,2 \%$ no número total de tratores, destacando-se que esta expansão ocorreu paralelamente ao au mento na potência dàs māquinas utilizadas. Enquanto que em $1971 \quad 57 \%$ dos tratores apresentavam potência igual ou superior a $45 \mathrm{HP}$, em 1979 esta participação subiu para $77 \%$. Outro indicador do processo de mé canização, a ārea trabalhada por trator, que era de 201 ha em 1971, pas sou a 104ha em 1979. Constata-se tambëm, que a taxa de crescimento do nūmero de tratores foi maior nas propriedades com ārea total atē 100, 0ha, principalmente nas de tamanho mini $(3,1$ a 20 , 0ha $)$, enquanto que, em termos absolutos o maior crescimento ocorreu nas pequenas pro priedades $(20,1$ a 100,0 ha $)$.

Segundo GHILARDI e BEMELMANS (1986) na década de se tenta houve uma conjugação de elementos favorāveis ao desenvolvimento do setor agrícola, relacionados à expansão da atividade econōmica, evo lução dos preços dos produtos e dos fatores, elevados subsidios para custeio, investimento e comercialização, alēm de grande disponibilida de de crédito. Por outro lado, a partir do final do período, princi palmente nos primeiros anos da década de oitenta, todos esses elemen tos evoluiram de maneira desfavorāve 1 aos produtores.

VICENTE (1985) analisou a evoliução do processo de meca. nização em nove atividades agrícolas paulistas na década de setenta, concluindo que soja, cana-de-açūcar, algodão e'arroz são produtos que possuiam, des de o início dos anos setenta, alto percentual de ārea com tração motomecânica na operação de aração, variando de $99,1 \%$ para so 
ja a $72,5 \%$ para arroz. Amendoim apresentava $40,6 \%$ e feijão $37,8 \%$. . Portanto, era bem significativa a ārea arada com trator no Estado, em 1970. Quanto à operação de plantio, o processo manual respondia por mais de $50,0 \%$ nas culturas de cana-de-açūcar e feijão (sem considerar laranja e café). Durante a década evoluiu consideravelmente o plantio mecanizado - por equipamentos motorizados e com animal.

Ainda no inïcio dos anos setenta, era representativo nas pequenas propriedades o percentual de ārea capinada com anima 1 e pro cesso manual para algodão, arroz, feijão, café, mi tho e amendoim, sen do que a tração motomecãnica nesta operação era mais utilizada na so ja $(60,8 \%)$, na cana-de-açūcar $(34,8 \%)$ e na laranja $(44,3 \%)$. A colhei ta motomecānica só era realizada de modo efetivo na cultura da soja $(98,2 \%)$

Considerando-se dados de 1975/76, 1979/80 e 1986/87, para as mesmas culturas analisadas por VICENTE (1985), podese constatar que houve significativo crescimento da ārea trabalhada com tração motomecãnica no Estado.

Em $1986 / 87$, o percentual de ārea arada com tração moto mecānica é superior a $90,0 \%$ para algodão, amendoim, arroz, mi iho, soja e cana-de-açūcar. Apenas feijão, apresenta percentual um pouco infe rior, ou seja $84,3 \%$ (Tabelas $5,6,7,8,9,10$ e 11).

Nos levantamento de $1975 / 76$ e $1979 / 80$, a informação so bre plantio referia-se à ārea plantada, por meio de processo manual e com equipamento (motomecanizado e animal). Em 1975/76, os percentuais de ārea mecanizada na operação de plantio eram de: 96,8\% para soja, $73,8 \%$ para mi tho, $94,3 \%$ jara algodão, $82,1 \%$ para amendoim, e inferio 
32.

Tabela 5.- Percentuais de Area de Algodão, Segundo o Tipo de Tração Uti lizada para cada Operação, Estado de São Paulo, 1975/76, 1979/80 e 1986/87.

\begin{tabular}{|c|c|c|c|c|}
\hline \multirow{2}{*}{$\begin{array}{c}\text { Ano Agrícola } \\
\text { e Processo }\end{array}$} & \multicolumn{4}{|c|}{ Operação } \\
\hline & $\overline{\text { Aração }}$ & Plantio $(1)$ & Capina & Colheita \\
\hline \multicolumn{5}{|l|}{$1975 / 76$} \\
\hline T. animal & 8,5 & - & 38,3 & - \\
\hline T. animal e motomec. & -. & 94,3 & - & - \\
\hline T. motomecânica & 91,5 & - & 21,4 & 6,5 \\
\hline Manual & - & 5,7 & 40,3 & 93,5 \\
\hline \multicolumn{5}{|l|}{$1979 / 80$} \\
\hline T. anima 1 & 10,0 & - & 28,4 & - \\
\hline T. animal e motomec. & - & 93,5 & - & - \\
\hline T. motomecânica & 90,0 & - & 33,0 & 11,0 \\
\hline Manua 1 & - & 6,5 & 38,6 & 89,0 \\
\hline \multicolumn{5}{|l|}{$1986 / 87$} \\
\hline T. animal & 4,7 & 8,5 & 12,4 & - \\
\hline T. motomecānica & 95,3 & 90,1 & 36,0 & 1,4 \\
\hline $\begin{array}{l}\text { Manual, com auxilio } \\
\text { de equip. motorizado }\end{array}$ & - & - & - & - \\
\hline Manua 1 & - & 1,4 & 36,9 & 98,6 \\
\hline Uso de herbicida & - & - & 14,7 & - \\
\hline
\end{tabular}

(1) Operação de plantio subdivide-se em manual e com equipamentos (moto mecanizado e animal), em 1975/76 e 1979/80.

Fonte de dados básicos: Instituto de Economia Agrícola (IEA) e Coorde nadoria de Assistência Técnica Integral (CATI) 
Tabela 6.- Percentuais de Area de Arroz, Segundo o Tipo de Tração Utili zada para cada Operação, Estado de São Paụ 0 1974/75, 1979/80 e 1986/87.

Ano Agrícola

e Processo

$\frac{\text { Operação }}{\text { Aração Plantio (1) Capina Colheita }}$

$1974 / 75$

T. animal

13,2

36,4

T. animal e motomec.

64,2

T. motomecânica

86,8

$-$

13,1

34,4

Manual

35,8

50,0

65,6

1979/80

T. anima 1

11,7

33,1

T. animal e motomec.

- $\quad 72,1$

T. motomecânica

88,3

$-$

21,9

43,0

Manual

$-$

27,9

45,0

57,0

1986/87

$T$. anima 1

T. motomecānica

$\begin{array}{rrrr}8,9 & 8,6 & 29,1 & - \\ 91,1 & 73,7 & 31,1 & 50,3 \\ - & - & - & 8,6 \\ - & 17,7 & 29,3 & 41,1 \\ - & - & 10,5 & -\end{array}$

(1) A operação de plantio subdivide-se em manual e com equipamento (mo tomecanizado e arimal), em 1975/76 e 1979/80.

Fonte de dados básicos: Instituto de Economia Agrícola (IEA) e Coorde nadoria de Assistēncia Técnica Integral(CATI) 
Tabela 7.- Percentuais de Área de Amendoim, Segundo o Tipo de Tração Uti Tizada para cada Operação, Estado de São Paulo, 1975/76, $1979 / 80$ e $1986 / 87$.

\section{Ano Agrícola}

e Processo

Operação

Aração Plantio ( $\left.{ }^{1}\right)$ Capina Colheita

$1975 / 76$

T. anima 1

32,4

34,9

T. animal e motomec.

T. motomecânica

Manual

67,6

82,1

1979/80

T. anima 1

T. animal e motomec.

26,5

- 90,1

73,5

17,9

15,8

4,5

\begin{tabular}{l}
$-\quad 17,9$ \\
\hline
\end{tabular}

49,3

95,5

T. motomecânica

Manual

1986/87

T. anima 1

T. motomecânica

Manual, com auxilio de equip. motorizado

Manua 1

Uso de herbicida
4,0

96,0

6,2

93,7

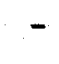

27,7

24,5

47,8

30,8

9,9

69,2

(') A operação de plantio subdivide-se em manual e com equipamento (mo tomecanizado e animal), em 1975/76 e 1979/80.

Fonte dos dados básicos: Instituto de Economia Agrỉcola (IEA) e Coorde nadoria de Assistência Técnica Integral (CATI) 
Tabela 8.- Percentuais de Area de Feijão, Segundo o Tipo de Tração Uti. 1izada para cada Operação, Estado de São Paulo, 1975/76, $1979 / 80$ e 1986/87.

Ano Agrícola

$\frac{\text { Operação }}{\text { Aração Plantio (l) Capina Colheita }}$

1975/76

T. anima 1

51,7

42,0

T. animal e motomec.

37,8

T. motomecânica

48,3

2,0

1,1

Manual

62,2

56,0

98,9

1979/80

T. animal

25,7

36,0

T. animal e motomec.

T. motomecānica

74,3

72,5

Manua 1

$-$

27,5

14,9

5,8

1986/87

T. anintal

15,7

6,6

20,6

T. motomecānica

84,3

74,3

24,1

6,4

Manua 7 , com auxilio

de equip.motorizado

Manual

Uso de herbicida

$\begin{array}{cccc}- & - & - & 37,9 \\ - & 19,1 & 33,8 & 55,7 \\ - & - & 16,5 & -\end{array}$

(') A operação de plantio subdivide-se em manual e com equipamentos(mo tomecanizado e anima 1), em 1975/76 e 1979/80.

Fonte dos dados bāsicos: Instituto de Economia Agrícola (IEA) e Coorde nadoria de Assistēncia Técnica Integral(CATI) 
36.

Tabela 9.- Percentuais de Area de Mi 1ho, Segundo o Tipo de Tração Utilizada para cada Operação, Estado de São Paulo,

1975/76, $197 ? / 80$ e $1986 / 87$.

Ano Agricola

e Processo

$\frac{\text { Colheita }}{\text { Aração Plantio }(1) \text { Capina Colheita }}$

$1975 / 76$

T. animal

15,2

39,3

T. animal e motomec.

73,8

T. motomecānica

84,8

27,1

30,3

Manua 1

26,2

33,6

69,7

$1979 / 80$

T. anima 1

11,0

27,4

T. animal e motomec.

80,9

T. motomecânica

89,0

$-$

45,8

48,3

Manual

19,1

26,8

51,7

$1986 / 87$

T. anima 1

T. motomecânica

8,7

6,2

16,4

91,3

82,0

59,9

56,0

Manual, com auxîlio

de equip.motorizado

T. motomecānica

Manual

Uso de herbicida
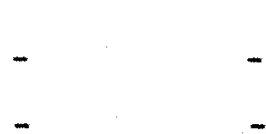

$-\quad 12,7$

$-\quad 11,8$

18,3

31,8

$-\quad-$

5,4

( ${ }^{1}$ ) A operação de plantio subdivide-se em manual e com equipamentos (mo tomecanizado e anima1), em 1975/76 e 1979/80

Fonte dos dados básicos: Instituto de Economia Agrícola (IEA) e Coorde nadoria de Assistēncia Técnica Integral(CATI) 
Tabela 10.- Percentuais de Area de Soja, Segundo o Tipo de Tração Utili zada para cada Operação, Estado de São Paulo, . 1975/76, $1979 / 80$ e $1986 / 87$.

Ano Agrícola

e Processo

$\frac{\text { Operação }}{\text { Aração Plantio ( }(1) \text { Capina Colheita }}$

$1975 / 76$

T. animal

T. animal e motomec.

0,1

$-\quad 96,8$

T. motomecānica

99,1

$-$

Manua 1

$-\quad 3,2$

63,3

98,9

$1979 / 80$

T. anima 1

3,8

99,6

T. animal e motomec.

$-$

$$
-
$$

T. motomecânica

96,2

$$
0,4
$$

27,5

1,1

Manua 1

-

1,5

1,5

2,2

1986/87

T. animal

T. motomecânica

Manual, com auxîi io

98,5

98,5

82,8

95,1

de equip motorizado

Manual

Uso de herbicida

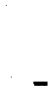

$\begin{array}{rrrr}- & - & - & 7,0 \\ - & - & 6,1 & 0,9 \\ - & - & 44,2 & -\end{array}$

(1) A operação de plantio subdivide-se em manual e com equipamentos (mo tomecanizado e anima 1), em 1975/76 a 1979/80.

Fonte dos dados bāsicos: Instituto de Economia Agrīcola (IEA) e Coorde nadoria de Assistēncia Técnica Integral(CATI) 
Fabela 11.- Percentuais de Area de Cana-de-Açūcar, Segundo o Tipo de Tração Utilizada para cada Operação, Estado de São Paulo, $1975 / 76,1979 / 80$ e 1986/87.

\begin{tabular}{|c|c|c|c|c|}
\hline \multirow{2}{*}{$\begin{array}{c}\text { Ano Agrícola } \\
\text { e Processo }\end{array}$} & \multicolumn{4}{|c|}{ Operação } \\
\hline & Aração & Plantio $\left({ }^{\top}\right)$ & Capina & Colheita \\
\hline \multicolumn{5}{|l|}{$1975 / 76$} \\
\hline T. animal & 5,4 & - & 17,2 & - \\
\hline T. animal e motomec. & - & 32,7 & - & - \\
\hline T. motomecânica & 94,6 & & 42,7 & 15,6 \\
\hline Manual & - & 67,3 & 40,1 & 84,4 \\
\hline \multicolumn{5}{|l|}{$1979 / 80$} \\
\hline T. animal & 3,3 & - & 6,4 & - \\
\hline T. animal e motomec. & - & 26,8 & - & - \\
\hline T. motomecânica & 96,7 & & 50,1 & 21,1 \\
\hline Manua 7 & - & 73,2 & 43,5 & 78,9 \\
\hline \multicolumn{5}{|l|}{$1986 / 87$} \\
\hline T. anima 1 & 1,9 & - & 2,8 & - \\
\hline T. motomecānica & 98,1 & - & 31,2 & 6,8 \\
\hline $\begin{array}{l}\text { Manual, com auxîlio } \\
\text { de T.motomecânica }\end{array}$ & - & 77,8 & - & 51,3 \\
\hline Manua 1 & - & 22,6 & 21,6 & 41,9 \\
\hline Uso de herbicida & - & - & 44,4 & - \\
\hline
\end{tabular}

(') A operação de plantio subdivide-se em manual e com equipamentos (mo tomecanizado e animal), em 1975/76 e 1979/80.

Fonte dos dados básicos: Instituto de Economia Agrícola (IEA) e Coorde nadoria de Assistência Técnica Integral(CATI) 
39.

res para arroz e feijão, com $64,2 \%$ e $37,8 \%$, respectivamente. Na canade-açūcar, o plantio ainda é efetuado geralmente pelo processo . ma nual, pois em geral as plantadeiras existentes são ainda de baixa efi ciēncia.

Os dados obtidos em 1986/87 possibilitaram separar o percentual de plantio por meio de plantadeiras motomecanizadas, de tra ção animal e de processo manual. Estimativas parà este ano mostram a predominancia do uso da tração motomecãnica na operação de. plantio. Pode-se constatar tambēm em 1986/87 a utilização de herbilci das, com percentuais de ārea representativos para soja e cana-de-açū car.

Os resultados obtidos indicam $44,2 \%$ para 0 uso de herbi cidas e $49,1 \%$ de capina com trator e implementos, totalizando $93,3 \%$ na cultura da soja, e $44,4 \%$ e $31,2 \%$ para cana-de-açūcar, resțando a penas $24,4 \%$ para o processo manual e tração anima 1 .

Em culturas como café e laranja, a utilização de herbi cidas é menor, ou seja $4,2 \%$ no café e $5,5 \%$ na laranja, respectivamente. A capina manual e a capina animal ainda são importantes no café, en quanto que na laranja o mais comum è a capina motomecânica e coroa ção manual (Tabelas 12 e 13).

Amendoim apresenta $69,3 \%$ de ärea capinada com uso de herbicida e tração motomecānica, algodão 50,7\%, e mi hho $65,3 \%$, enquan to que arroz e feijão embora possuam percentuais inferiores a $50 \%$ $(41,6 \%$ para arroz e 40,6\% para feijão), mostraram significativa ado ção de capina motomecanizada, de 1979/80 para 1986/87.

Na operação de colheita, o uso de colheitadeiras ē 
Tabela 12.- Percentuais de Ärea de Laranja, Segundo o Tipo de Tração Uti Tizada para a Operação de Capina, Estado de São Paulo, 1975/ $76, \quad 1979 / 80$ e $1986 / 87$.

\begin{tabular}{lccc}
\hline Processo & $1975 / 76$ & $1979 / 80$ & $1986 / 87(1)$ \\
\hline T. animal & 1,4 & 1,6 & 1,6 \\
T. motomecânica & 49,7 & 48,8 & 75,3 \\
Manua 1 & 48,9 & 49,6 & 17,6 \\
Uso de herbicida & - & - & 5,5 \\
\hline
\end{tabular}

(') Em 1986/87, o processo manual refere-se apenas à capina com enxada no pomar todo. A informação relativa à coroação manual foi coleta da separadamente, visto que geralmente é efetuada em complemento à capina mecànica nas ruas e linhas.

Fonte de dados básicos: Instituto de Economia Agrícola (IEA) e Coorde nadoria de Assistēncia Técnica. Integral(CATI). 
Tabela 13.- Percentuais de Area de Café, Segundo o Tipo de Tração Utili zada na Operação de Capina, Estado de São Paulo, 1975/76, $1979 / 80$ e $1986 / 87$.

\begin{tabular}{lccc}
\hline Processo & $1975 / 76$ & $1979 / 80$ & $1986 / 87\left({ }^{\prime}\right)$ \\
\hline T. animal & 23,0 & 24,0 & 25,6 \\
T. motomecānica & 17,5 & 19,7 & 22,8 \\
Manual & 59,5 & 56,9 & 47,4 \\
Uso de herbicida & - & - & 4,2 \\
\hline
\end{tabular}

(') Em 1986/87, o processo manual refere-se apenas à capina com enxada no cafezal todo. A informação relativa à coroação manual foi cole tada separadamente.

Fonte dos dados básicos: Instituto de Economia Agrícola (IEA) e Coorde nadoria de Assistência Técnica Integral (CATI) 
maior na soja $(92,1 \%$ da ārea colhida, em 1986/87), notando-se decrésci mo com relação a $1979 / 80$, o que poderia ser explicado pelo fato de que pequenos produtores que se utilizam de trabalho intensivo na produção de feijão, arroz e outras culturas tenham passado a produzir soja de vido à boa rentabilidade da cultura.

Mi tho e arroz apresentaram $56,0 \%$ e 50,3\% de àrea CO Thida motomecánicamente em $1986 / 87$, sendo que no amendoim o processo mais utilizado seria a colheita manual com auxítio de equipamentos mo torizados $(65,9 \%)$. No feijão, a colheita manual corresponde a $55,7 \%$ da ārea total e a manual com auxîlio de equipamentos motorizados cor responde a $37,9 \%$.

Quanto ao algodão, que apresentou $11,0 \%$ de ārea colhida por meio de colhedeiras em 1979/80, decresceu para 1,4\% da ārea total em 1986/87. Provavelmente uma das causas seria que as colhedeiras e xistentes (importadas) sujam muito o algodão, são imprōprias para ter renos com declive e não se adaptam ao espaçamento. Outra possível van tagem comparativa da colheita manual seriao barateamentorelativo da mesma.

Na cana-de-açūcar, o uso de colhedeiras não é comum, $(6,8 \%$ da ärea total colhida, em 1986/87), salientando-se o elevado cus to das mesmas. Nesta cultura, utiliza-se, na colheita, a car regadeira. Os percentuais obtidos para colheita motomecánica em 1975/76 e 1979/80 são superiores ao de 1986/87 o que pode se dever tam bēm ao fato de não se especificar o tipo de máquinas usada: colhedeira ou carregadeira, incorporando desta forma, a informação, não sō a co The deira mas tambēm outros tipos de mäquinas auxiliares ao processo de colheita. 


\section{METODOLOGIA}

Antes da apresentação do mode 10, faz-se algumas referēn cias de estudos prōximos aos objetivos pretendidos e que auxiliam em parte na indicação de variāveis propostas.

SCHUH (1962) obteve estimativas da demanda e oferta pa ra a força de trabalho temporário na agricultura americana. Estudou 0 período 1929-1957. A oferta de trabatho foi expressa como função do salārio real da força de trabalho agrícola, salärio não agrícola, a força de trabalho civil e o desemprego da economia. A equação de de manda por trabalho agrícola foi expressa em função de: salārio real da força de trabalho agrícola, um indíce de preços dos produtos agrīcolas, um indice de preços dos insumos e uma medida de tecnologia.

SAYLOR (1974) estimoụ equações estruturais de procura e oferta de trabalho agrícola em São Paulo. Utilizou o modelo bási co de equações simultāneas desenvolvido por SCHUH (1962). A oferta de trabalho foi especificada como função do salārio real, renda não agrí cola, imigração de outros estados e de uma tendencia secular; a procu ra foi especificada como função do salārio real, um indice de produti vidade utilizada como substituto para a mudança tecnológica, preços pagos e preços recebidos pelos agricultores e uma variāvel representa tiva da legislação trabalhista. Cada uma das equações estruturais foi estimada com e sem a pressuposição de uma resposta defasada dos ofer tantes e consumidores de trabalho. 0 período coberto foi de 1948-70. 
0 mode 10 usado por Saylor diferiu do proposto por Schun em quatro aspectos:

a) incluiu uma variāvel migração.

b) a força de trabalho civil não foi utilizada como vạ riāivel deslocamento da equação de oferta.

c) a renda não agrícola não era corrigida pela taxa de desemprego.

d) foi feita uma tentativa para captar a influência da legislação rural na procura de trabalho.

GASQUES (1975) estimou equações de oferta e demanda de trabalho volante no Estado de São Paulo, considerando o período 1969 a 1974. As variāveis utilizadas no estudo foram: quantidade de mão-deobra volante no Estado de São Paulo, salārio diārio da mão-de-obra vo lante, salārio diārio da mão-de-obra diarista residente, salārio mí nimo oficial vigente na capital, relação preços recebidos e' preços pa gos pelo produtor rural, preço de tratores em São Paulo (Capital), sen do que tais preços referem-se ao trator Massey-Ferguson $44 \mathrm{HP}$, indi ce de produtividade agrīcola em São Paulo como "proxy" de tecnologia, três variäveis binärias para os meses de março, junho e novembro, e uma tendencia expressa em meses.

No presente estudo, serão consideradas nas equações de demanda e oferta de trabatho volante variāveis cujos efeitos não pude ram ser avaliados adequadamente, antes, devido à inexistēncia de da dos. 0 uso de tração motomecānica na equação de demanda seria um exem plo. Estudos anteriores utilizaram a variāvel preço de tratores para avaliar o efeito de mecanização no uso de mão-de-obra. Saliente-se, 
porēm, que mudanças no preço do trator tenderiam, no curto prazo, a. afetar mais a aquisição de tratores do que a utilização dos mesmos. Procurar-se-à também avaliar as relaçōes entre o tra balho volante e o residente, por meio da variāvel nümero de tra balhadores residentes empregados na agricultura paulista.

Considerar-se-à o emprego nos setores industrial e da construção civil como variāvel deslocadora na equação de ofer ta.

Acredita-se, desta forma, poder acrescentar novas in formaçōes sobre o mercado de mão-de-obra volante no Estado de São Paulo.

\subsection{O Mode 10}

Na economia neoclāssica, a demanda por trabalho è de rivada da função de-1ucro da empresa. Supondo-se existir um mercado competitivo, é necessārio que o acréscimo de produção, devido ao empre go de um trabalhador adicional, multiplicado pelo preço do produto se ja igual à taxa de salārio (FERGUSON, 1976).

Desta forma, um empresārio maximizador de lucro emprega rā unidades de um serviço produtivo variāvel até que seja atingido o ponto onde o valor do produto marginal do insumo é exatamente igual ao preço do insumo. 
A oferta de trabalho de um indivídulo pode, em princí. pio,ser determinada pela anālise das curvas de indiferença. 0 salā rio não se constitui no ünico elemento no qual se baseia a decisão de trabalho do individuo, pois leva-se em conta também, a natureza do trabalho, a regularidade, a segurança e o grau de independēncia (FERGU SON, 1976).

As equações de oferta e demanda de trabalho volante se rão estimadas por meio do método de Mĩnimos Quadrados em Dois Estāgios. A justificativa para o uso de modelos simultāneos ba seia-se na pressuposição de que a oferta e a procura variam simultanea mente, determinando assim diferentes pontos de equilíbrio ao longo do período analisado (Lange, citado por GASQUES, 1975).

Alguns pontos devem ser observados com relação ao sistema de equações, dentre os quais se o sistema é completo. Dizse que um sistema è completo quando o número de equações $\bar{e}$ igual ao nūmero de variáveis endógenas de forma que o sistema possa ser re solvido para essas variāveis. A solução é chamada forma reduzida do sistema. Uma equação na forma reduzida mostra como uma variā vel conjuntamente determinada (endōgenas correntes), varia em fun ção das variāveis prē-determinadas e dos erros aleatōrios. As equa ções originais são chamadas equações estruturais, e para que uma equação estrutural seja identificāvo 1 , ē condição necessāria que o nümero de variāveis prē-determinadas do sistema, que não aparecem nesta equação seja, ao menos, igual a’o nümero de variāveis endó genas correntes presentes no segundo membro dessa equação (HOFFMANN E VIEIRA, 1977). 
47.

testes de Durbin-Watson, "F", "t" são vālidos e podem ser interpreta dos de modo usual na forma reduzida. Já no segundo estägio, o $R^{2}$ não ē mais estritamente välido. Da mesma forma, os testes de hipō teses convencionais " $F$ " $e$ " $t$ " não são mais testes estatísticos estrita mente vālidos. Utiliza-se, frequentemente, uma regra prātica, que consiste em comparar os valores absolutos dos parāmetros estimados com seus respectivos desvios-padrões. Se o coeficiente de uma variāvel na equação estrutural è maior ou igual ao-seu desvio-padrão, este $\bar{e}$ considerado "significativo". Se o coeficiente ē pelo menos o dobro de seu desvio-padrão, o analista econōmico pode ficar razoavelmente se guro de sua significāncia. O teste de Durbin-Watson não ē mais vāli do e realmente não deve ser usado para testar a córrelação serial (MARSHALL E. PERES, 1973 ).

As equações estruturais da demanda e da oferta de mãode-obra volante a serem estimadas são:

Demanda :

$Q V=f\left(S V, I P D, T M, Q T R, T_{1}, T_{2}, T_{3}, D_{1}, D_{2}, D_{3}, D_{4}\right)$

Oferta:

$Q V=f\left(S V, S M\right.$, POICC, $\left.T_{1}, T_{2}, T_{3}\right)$

onde:

QV = nūmero de trabalhadores volantes empregadosna $\underline{a}$ gricultura paulista.

SV = salärio da mão-de-obra volante.

IPD = relação indice geral de preços recabidos/indice geral de preços pagos na agricultura paulista.

TM = percentual de ārea trabalhada com tração motome cānica nas operaçōes de capina e colheita. 
QTR = população trabalhadora residente nos imóveis ru rais.

$$
\begin{aligned}
& \text { SM = salārio mínimo vigente no Estado de São Paulo. } \\
& \text { POICC = pessoal ocupado na incústriade transformação, ou }
\end{aligned}
$$
tras atividades industriais e na construção civị.

$$
\begin{aligned}
& T_{1}, T_{2} \text { e } T_{3}=\text { tendēncias temporais } \\
& D_{1}, D_{2}, D_{3}, D_{4}=\text { variāveis binārias. }
\end{aligned}
$$

A quantidade e o salārio de volantes são variāveis en dōgenas e determinadas conjuntamente, pelas variāveis exōgenas e os er ros.

Para estimar os parāmetros das equações (1) e (2) por meio de método de Minimos Quadrados em Dois Estāgios, deve-se efetuar inicialmente, a regressão de SV (a variāvel endōgena que aparece no se gundo termo das equações) em relação às variāveis exōgenas do sistema. No segundo estāgio, faz-se a regressão de QV em relação à SV (estimado no primeiro estägio) e as variäveis exōgenas.

2.2. Cālculo das Variāveis Utilizadas nos Modelos de Oferta e Demanda de Mão-de-Obra Volante

QV = Nümero de trabalhadores volantes, com mais de quin ze anos, empregados no setor agrícola do Estado de São Paulo no perío do de novembro de 1974 a setembro de 1987. Essa informação é obtida 
por meio de cinco levantamentos anuaịs: fevereiro, abril, junho, setem bro e novembro, nos quais se coleta o número de volantes por sexo e $i$ dade (menos e mais de 15 anos). Desta forma, tomou-se o nümero de volantes nesses cinco meses do ano agrícola, exceto para alguns meses em que não se dispõe das informações. Saliente-se que os dados refe rentes ao período de junho de 1981 a novembro de 1984 não estão dis poniveis, uma vez que os levantamentos não foram processados.

0 conceito utililizado pelo IEA considera como volan tes, os trabalhadores contratados nas cidades vizinhas ao imōvel e transportados em grupo para o local de trabalho.

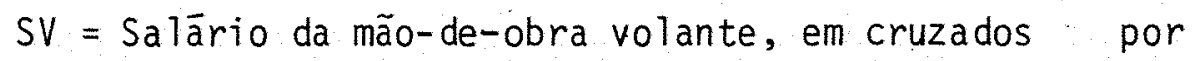

dia, de novembro de 1974 à setembro de 1987. Este dado tambēm foi ob tido por meio dos cinco levantamentos anuais efetuados pe lo IEA. Para cada més considerado calculou-se a média da diāria paga ao trabalhador volante homeme mulher, ponderando-se o valor da diāria pelo nümero de volantes homens e mulheres. Os valores resultantes foram defla cionados pelo Indice Geral de Preços (coluna 2 da Conjuntura Econōmica, da Fundação Getūitio Vargas).

SM = Salārio mīnimo vigente no Estado de São Paulo, de novembro de 1974 a setembro de 1987, em cruzados por dia. Para o cāl culo dessa variāvel utilizou-se o més de 25 dias de trabalho, conside rando-se também 0 130 salärio. Os valóres obtidos foram então defla cionados pelo Indice Geral de Preços (coluna 2 da Conjuntura Econōmica, da Fundação Getūlio Vargas).

$I P D=$ Relação entre 0 indice geral de preços recebidos e o indice geral de preços pagos pela agricultura paulista, tambëm 
chamado de indice de paridade ou relação de trocas calculadas com ba se $1966=100$. O indice de preços recebidos pelo agricultor $\bar{e}$ cal culado mensalmente, atravēs, das cotações dos seguintes produtos vege tais: amendoim, arroz, banana, batata inglesa, café, cebola, chā, fei jão, laranja, mamona, mandioça, milho, soja e tomate. Constam, tam bém os preços de bovinos, suínos, frango ou galinha para corte, leite e ovos.

0 indice de preços pagos pelos agricultores inclui os se guintes grupos: māquinas e equipamentos, fertilizantes, defensivos, va cinas e medicamentos, combustiveis e Tubrificantes, material de cons trução, utensilios e ferramentas, animais de trabalho e produção, ser viços comprados (transporte rodoviārio, ferroviārio e energia elētri ca), alimentos de origem agrícola.

Este indice serā defasado em relação à quantidade de volantes, pois acredita-se que a relação favorāvel de preços vigen tes em uma dada safra, afetaria o emprego da mão-de-obra na safra se guinte, ou seja, a quantidade de trabalhadores em um dado mês seria função dos indices que levaram à decisão de plantio.

Foi, então, efetuada a média com os seis meses que an tecedemomês de novembro de cada ano agrícola, e este valor foi conside rado atē setembro do ano posterior.

A inclusão dessa variāvel baseia-se na hipōtese de que as relações favorāveis ao agricultor, em termos de preços recebidos - e preços pagos, fariam com que o mesmo aumentasse a produção e, conse quentemente, necessitasse de mais mão-de-obra (acrēscimo na demanda). $T M=$ Percentual de ārea com tração motomecānica nas ope 
rações de capina e colheita. Para o cālculo dessa variāvel efetuou-se inicialmente a soma das āreas em que foi utilizada tração motomecānica na operação de capina para os produtos: algodão, amendoim, arroz, fej jão, milho, soja, cana-de-açūcar, laranja e café. Com relação à co Theita, somente a ārea colhida motomecanicamente nas culturas anuais e semi perenes foi somada à àrea capinada, pois nas cúlturas perenes a colheita é quase que exclusivamente manual.

Uma vez que o levantamento de "Medição da Técnica . Em pregada" não foi efetuado para todos os anos, e sim para 1974/75, $1975 / 76,1979 / 80,1985 / 86$ e 1986/87, estimou-se o percentual para os anos não coletados atravës de uma regressão.

Consideraram-se as operações de capina e colheita pois são aquelas que mais utilizam mão-de-obra. o preparo do solo e 0 plantio jā se encontravam com alto percentual de ārea motomecanizada em $1974 / 75$.

A interpretação do coeficiente desta variävel, possibi litarā uma avaliação do efeito da intensificação do uso de tração mo tomecānica sobre o emprego de volantes. Se a variāvel apresentar coe ficiente positivo, indica que tração motomecānica e volantes são com plementares no processo produtivo, ou seja, a intensificação do uso de tração motomecānica aumentaria a demanda por volante. Caso ocor ra o inverso, se o sinal do coeficiente for negativo, tração motome cãnica e mão-de-obra volante apresentam-se como substitutos.

QTR = Nümero de trabalhadores residentes nos imōyeis rü rais. Para alguns anos do perīodo analisado, os cinco levantamentos a nuais sobre mão-de-obra incluiram questōes sobre o emprego de residen 
tes nos imóveis rurais, enquanto que em outros anos havia valores para um, dois, trēs ou quatro-meses. Calculou-se então, a média destes le vantamentos, correspondendo ao período de novembro de um dado ano a setembro do ano posterior. Estão incluidos no total de residentes: proprietārios e familiares, mensalistas, diáristas, colonos, parceiros, arrendatārios e outros trabalhadores residentes no imōvel. Construiu-se, assim, um indice de quantidade com base 1974/75 = 100 .

Pretende-se avaliar, com a inclusão desta variävel na equação de demanda, se o trabatho residente e o volante são complementa res ou substitutos no processo de produção.

POICC = Indice de pessoas ocupadas na indūstria de trans formação, na construção civiil e em outras atividades industriais, que recebem atē dois salārios mínimos por mês. Acredita-se que alterações noemprego nos setores industrial e da construção civill, no Estado de São Paulo, possam afetar a oferta de trabalho volante.

$T=$ Tendencia temporal. Corresponde ao perīodo de no vembro de 1974 a setembro de 1987, sendo novembro de $1974=1$ e setem bro de $1987=155$.

$$
D_{1}, D_{2}, D_{3} \text { e } D_{4}=\text { Para captar as diferenças entre os meses }
$$

dos levantamentos, serão utilizadas quatro variāveis binārias: $D_{1}$ assu me valor 1 no levantamento de fevereiro e zero nos demais; $D_{2}$, valor 1 no levantamento de abril e zero nos demais; $D_{3}$, o valor 1 no levantamen to de junho e zero nos demais e, $D_{4}$, valor 1 no levantamento de setem bro e zero nos demais. Para o levantamento de novembro todas as qua tro variāveis são iguais a zero. 


\subsection{Fontes de Dados}

Os dados utilizados nos cālculos das variāveis quantida de de trabalho, diārias pagas aos volantes, uso de tração motomecānica e população trabalhadora residente nos imōveis rurais, tiveram como fonte o levantamento objetivo (por amostragem) efetuado pelo Instituto de Economia Agrícola.

As estimativas sobre trabatho volante na agricultura paulista são obtidas desde 1964, em levantamentos efetuados juntamente com os de estimativas e previsões de safras, a partir de questionārjos levantados pela Coordenadoria de Assistēncia Técnica Integral (CATI).

Des de 1950, quando foram criados, atē 1973, os levanta mentos passaram por alterações tanto na parte metodológica quanto no número de elementos da amostra (VICENTE et alii, 1988, NEGRI et alii, 1989 e CAMARGO et alii 1989).

Em 1974, calculou-se nova amostra duplamente estratifi cada (por tamanho de imōvel e por Divisão Regional Agrícola) utilizan do para tal fim o cadastro de imóveis rurais do INCRA, referente ao ano de 1973, constituîdo por 257.955 imōveis em todo o Estado. Atē junho 1977, eram encaminhados (ou endereçados) a campo 6.229 elementos. Em agosto de 1977, sorteou-se outra amostra (sem alterações na metodo logia de cālculo), que vigorou até abril de 1981, constituida de 5.646 elementos (maiores detalhes em CAMPOS e PIVA, 1974).

A partir do levantamento de junho de 1981, passou-se a utilizar a amostra retirada da relação cadastral do INCRA vigente no 
ano de 1979, com 3.622 elementos subdivididos em 1.811 subestratos, lé vando em consideração. doze estratos de ārea, dez DIRAs e dois grupos de municīpios por DIRA, com representatividade a nīvel de Divisões Regio nais Agrícolas (CAMARGO, 1988).

Em setembro de 1986 adotou-se a mesma estrutura de amos tragem de CAMPOS E PIVA (1974), permanecendo a amostra com 3.622 ele mentos.

As questões sobre número de trabalhadores volantes, di $\underline{a}$ rias pagas e número de trabalhadores residentes fazem parte do questio nārio sobre demografia e mão-de-obra, enquanto que uso de tração motome cânica foi obtido por meio do questionārio de medição da tēcnica em pregada.

Os dados referentes às relações de troca (relativos de preços de produção e preços de insumos) são publicados pelo IEA, na re vista mensal Informações Econōmicas; os salärios mínimos provēm dos Anuārios Estatíticos do Brasil. O número de pessoas ocupadas no setor industrial e na construção civil no Estado de São Paulo (que recebem $\underline{a}$ té dois salārios minnimos) foi obtido na pesquisa nacional por amostra de domicitio (PNAD).

A escolha do periodo a ser analisado foi determinada de acordo com a disponibilidade dos dados. As informações sobre a medi ção dâ tëcnica empregada, por exemplo, estão disponiveis para alguns anos das décadas de setenta e oitenta, e os meses em que se efetuavam os levantamentos no periodo anterior a 1975 eram diferentes dos atuais. 
Os resultados dos modelos ajustados são apresentados na Tabela 14. As regressões foram ajustadas com as variāveis medidas tan to na forma linear quanto na forma logarítmica, sendo que os resułtados em termos de significāncia estatística, apresentaram-se methores na forma logarítmica. Nesta, os coeficientes das variāveis independentes fornecem diretamente as elasticidades. As variāveis binārias e a ten dēncia não foram aplicados logarítmos.

$\mathrm{Na}$ equação de demanda, os coeficientes de regressão a presentaram-se maiores que os respectivos erros-padrões para: a variā vel binäria $D_{3}$ (representativa do levantamento de junho), para o percen tual de ārea com tração motomecânica na capina e colheita e para a va riāvel relações de troca na agricultura paulista. 0 coeficiente da va riāvel população trabalhadora residente nos imōveis rurais, mostrou-se duas vezes maior que o respectivo erro padrão.

Com relação à equação de oferta, o coeficiente da variā vel salärio de volantes apresentou-se pelo menos duas vezes maior que o respectivo erro-padrão, enquanto que o coeficiente da variāvel saiārio mīnimo foi maior que o respectivo erro-padrão. Não foi significativo o. coeficiente estimado para a variāvel nümero de pessoas ocupadas nos se tores industrial e da construção civil. 
Tabela 14. - Estimativas dos Modelos de Oferta e Demanda de Mão-de-obra Volante no Est. de São Paulo, Nov.1974-Set.1987.

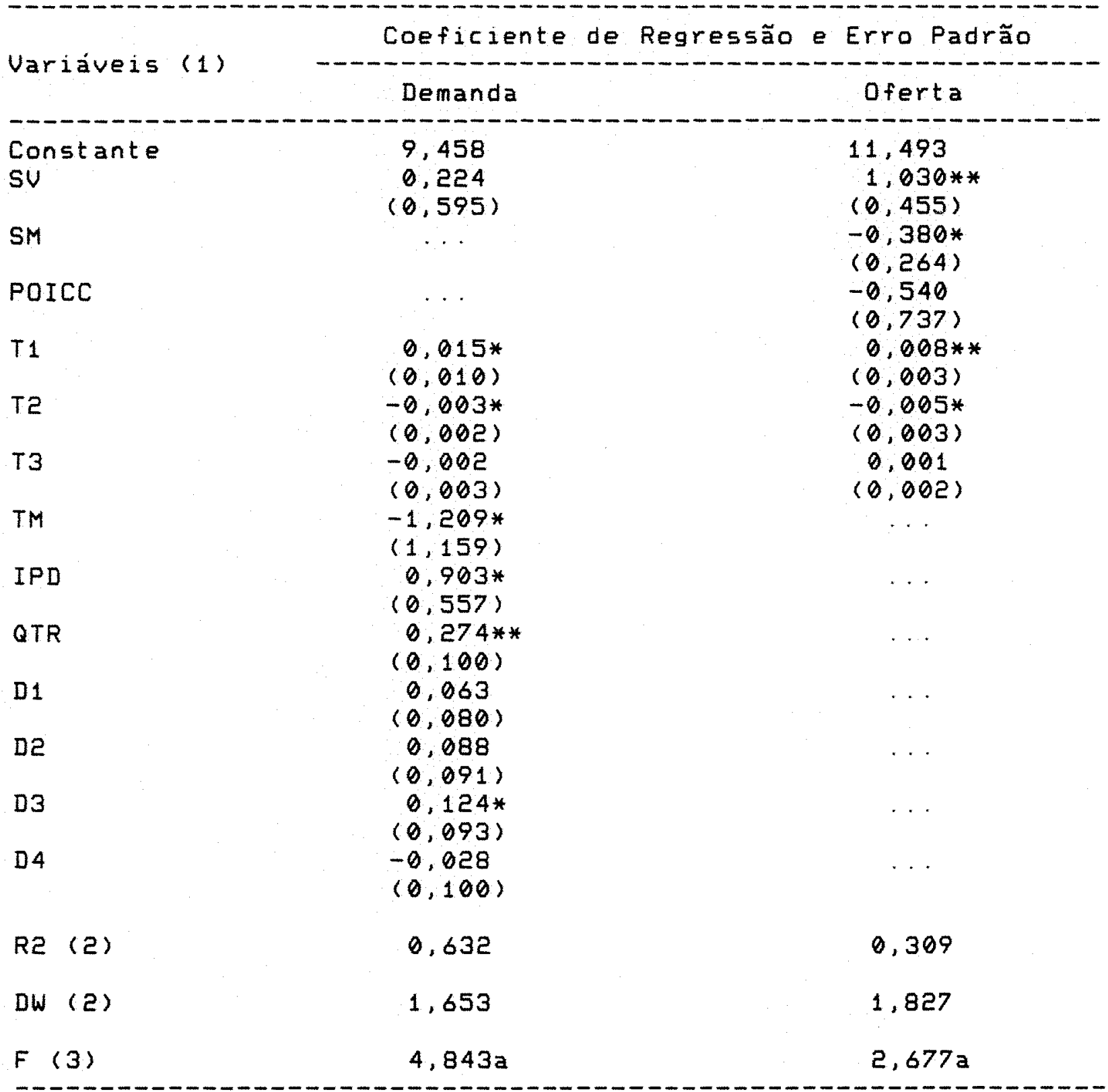

(1) Os valores das variáveis foram transformados em logaritmos, exceto a tendência e as variáveis binárias.

(2) 0 coeficiente R2 e o teste DW (Durbin-Watson) não são estritamente válidos na forma estrutural e devem ser interpretados com cautela.

(3) o teste $F$, apesar de não ser estritamente válido, foi apresentado para dar uma idéia do nivel de significância de cada equação (a = significativo a $5 \%$ ).

(*) o coeficiente estimado é maior que o respectivo erro padrão. (**) 0 coeficiente estimado é, pelo menos, duas vezes maior que seu erro padrão. 
Para inclusão da variāvel tendēncia temporal, o período compreendido entre novembro de 1974 a setembro de 1987 foi numerado se quencialmente, mês a mês, de 1 a 155 , como foi mencionado anteriormen te.

Uma anālise gräfica do nümero de trabalhadores volantes empregados ao longo tempo, indicou haver uma tendência de crescimento de novembro de 1974 a junho de 1979 , sendo que a partir de então, a série passa a apresentar tendéncia decrescente, que permanece até a bri1 de 1981. Posteriormente, com a retomada da série de dados do IEA, em fevereiro de 1985, não se observa mais o movimento descendente. Por este motivo, na tentativa de captar as diferenças de tendēncia nes tes três períodos, foi utilizada a técnica de ajuste de uma poligonal que consiste em criar, inicialmente, duas variāvies binārias $z_{1}$ e $Z_{2}$.

A variāvel $Z_{1}$ assumiu valor zero de novembro de 1974 a junho de 1979 e valor um a partir de então, $z_{2}$ assumiu valor zero de novembro de 1974 a abril de 1981 , e valor um nos meses posteriores. Em seguida, foi calculada $T_{2}=Z_{1} \times T_{1}$ e $T_{3}=Z_{2} \times T_{1}$. 0 coeficiente estimado para a tendência no primeiro período è o referente $\bar{a}$ variā vel $T_{1}$, para o segundo perịodo é a soma dos coeficientes de $T_{1}$ e $T_{2}$, e para o terceiro periodo e a soma dos coeficientes de $T_{1}, T_{2}$ e $T_{3}$. 
58.

3.1. Demanda

0 coeficiente de elasticidade-salārio da demanda permite avaliar as alterações na quantidade de mão-de-obra volante empregada, mediante as variaçóes salariais observadas para a categoria. Este coe ficiente não apresentou significāncia estatística indicando, portanto, relativa inelasticidade-salärio da demanda, a curto prazo. Sobre este aspecto, caberia destacar a importãncia desta mão-de-obra no processo de produção agrícola, uma vez que diversas operações agrícolas (colheita das culturas anuais, de cana-de-açūcar, de laranja tratos culturais das lavouras, etc.) são realizadas quase que exçiusivamente por trabalhado res temporärios. Desta forma, a demanda por volantes apresenta-se es tável face à variações no salārio, a curto prazo, em decorrēncia da ne cessidade de realização das operações agrícolas.

A título de comparação, GASQUES (1975), estimou um coe ficiente de elasticidade demanda de $-1,63$ para mäo-de-obra volante no Estado de São Paulo, no período 1969-74, enquanto que SAYLOR (1974), ao considerar a força de trabalho total na agricultura paulista, obteve um coeficiente relativamente inelästico para o período, 1948-70.

Com relação aos efeitos da motomecanização sobre o empre go de volantes, o coeficiente da variāvel percentual de ärea com uso de tração motomecānica nas operações de capina e colheita, das princi pais culturas da agricultura paulista, por ser negativo sugere substitui ção entre a mecanização e mão-de-obra volante. O resultado obtido in dica que um acréscimo de $1 \%$ no percentual de ārea motomecanizada 
proporcionaria um decréscimo de $1,2 \%$ no emprego de volantes.

De acordo com GRAZIANO DA SILVA (1980), nos anos setenta, observa-se ainda a redução da força de trabalho residente e a demanda de trabalhadores temporārios diminui o seu ritmo de crescimento, uma vez que as culturas que se expandem nos anos setenta absorvem menos mão-deobra por unidade de ärea, o que se deve ao fato de utilizarem mais inten samente insumos modernos, e porque o progresso tēcnico não se fez apenas via tratores (que reduzem empregos permanentes), mas tambēm via colheta deiras e defensivos, que reduzem a demanda por trabalhadores temporärios.

A colheita, por ser ainda manual em diversos produtos a grícolas e parcial em outros ē a grande fonte de emprego temporārio,mas jă existem opçōes tecnicamente satisfatōrias para a colheita mecānica das principais culturas temporärias. No caso de culturas perenes obser vam-se dificuldades.

"A anālise econōmica efetuada pará o caso do algodão e da cana-de-açūcar mostrou que a colheita mecānica ēviāvel a partir de uma de terminada escalá de produção" (KAGEYAMA et alii, 1981, p. 128).

Salientam, porēm, os autores acima citados que não apenas a estrutura de produção agrícola limita .o uso de colhetadeiras. E ne cessārio que se processem alterações nas prōprias culturas (espaçamento, padronização da altura dos pēs, comprimento dos talhões, etc.) para que as colhedeiras possam operar com uma eficiēncia de campo razoāvel, alēm de transformáções nas unidades receptoras dos produtos (usinas, fäbricas, silos, etc.) e nos meios de transporte (caminhões especiais, carreadores mais largos) para que se posssam obter ganhos de escala em função do maior volume colhido por unidade de tempo.

Para que se processem as transformaçōes necessärias ē pre 
ciso um certo período de tempo, que serā maior ou menor em função dos custos e das receitas adicionais envolvidas. Essas modificações se rão introduzidas, e a medida que forem contribuindo para melhorar o desempenho das colhedeiras, aumentarão as vantagens destas em rela ção à colheita manual.

A variāvel preços recebidos pelo agricultor em rela ção aos preços pagos, apresentou sinal positivo,e mostra portanto, que relações de preços favorāveis ao agricultor refletem-se positivamente sobre a demanda de trabalho volante. 0 valor estimado para o coefi ciente e de 0,9 e indica que um acréscimo de $1 \%$ na relação de trocas estā associado a um acrēscimo de 0,9\%naquantidade demandada de volan tes. Preços favorāveis ao agricultor, o incentivarão a plantar mais, e desta forma a demanda por mão-de-obra seria maior.

Quanto à variāvel população trabalhadora residente nos imóveis rurais, o resultado obtido sugere que volantes e residentes (proprietário, diarista, mensalista, arrendatārio, parceiro, colo no e outros) possuem uma relação de complementariedade na produção a grícola.

Alguns fatos inerentes ao processo produtivo da agricul tura paulista, favorecem a constatação acima citada. A modernização de grande parte dos imōveis rurais, possibilitou a permanencia nes tes imōveis, dos trabalhadores necessārios a parte do processo pro. dutivo, ou seja, o proprietārio e seus familiares, o administrador, 0 . operador de mäquinas, retireiros, e todos aqueles que executan tare fas diārias na fazënda. O volante seria, então, contratado para ope rações eventuais, como por exemplo, tratos culturais e colheita, que 
necessitam de um grande nümero de trabalhadores.

0 decréscimo da mão-de-obra residente no meio rural, ob servado desde os anos cinqlenta, ocorre com menos intensidade no final da década de setenta, com totais estimados de 844 mi 1, em 1977, 825 mi 1, em 1978 e 870 mi 1 , em 1979. Comparando-se estes valores com a es timativa obtida em 1985 , que foi de 848 mil trabalhadores, pode se constatar que o total estimado em 1985 é um pouco superior daquele ob tido em 1977 (VICENTE e BAPTISTELLA, 1986).

Desta forma, situação favorável à agricultura poderia gerar empregos tanto para mão-de-obra residente quanto para o traba Tho volante, devido à diferente atuação de cada um no processo de produção.

Com relação às variāveis binārias, que representam pos siveis alterações da demanda entre novembro e os meses de fevereiro, abri1, junho e setembro, o coeficiente foi significativo para junho época de colheita da cana-de açūcar.

A significāncia estatística de $T_{1}$ e $T_{2}$, indica diferen ças de tendéncia entre os períodos novembro de 1974 a junho de 1979 , e setembro de 1979 a abril de 1981. O coeficiente positivo de $T_{1}$ pode es tar captando a crescente utilização do volante em operações como por e xemplo a colheita de algodão, cana-de-açūcar e laranja para as quais não tem a curto prazo opçōes para se reduzir o uso de mão-de-obra. 
Na retomada da sērie, a não significāncia do coeficiente $T_{3}$, mostra que não houve alteração na tendēncia, no período de feve reiro de 1985 a setembro de 1987 , em relação ao período anterior.

\subsection{Oferta}

0 coeficiente de elasticidade-salārio foi estimado em 1,03, a curto prazo, indicando que um acrēscimo de $1 \%$ no satärio da ca tegoria, proporcionaria um aumento de $1,03 \%$ na quantidade ofertada.

Ao comparar o resultado acima, com aquele obtido por GAS QUES (1975), de 3,41 para o período 1969-74, nota-se que oferta de mãode-obra volante tornou-se menos elästica. Segundo o mesmo autor, o coe ficiente estimado justificava a despreocupação dos empresārios ru rais quanto a arregimentação de mão-de-obra não qualificada, pois nas épocas de colheita, em que mão-de-obra se torna escassa, ē possível ga rantir a força de trabalho com a oferta de maior preço.

Atē meados da década de setenta, foi significativa.a que da do nümero de trabalhadores residentes no imōve1. Muitos que deixa vam o campo, não conseguiam emprego no setor urbano, e passavam, então, a fazer parte da mão-de-obra volante. Mas, a partir da metade dos a nos setenta, a queda da população trabalhadora residente passa a ser bem menos significativa que aquela observada anteriormente. Atualmente 
o nümero de trabalhadores residentes è rẹlativamente estável.

A garantia da força de trabalho necessāria ao setor $\underline{a}$ grícola tem sido feita tambēm por meio de migrantes de outros Estados, o que representa custos mais elevados para mão-obra volante (transpor te, manutenção, etc.).

A título de ilustração, uma das mais importantes re giões de atração sazonal de migrantes seria a região canavieira de Ri beirão Preto - SP. De acordo com levantamento da Fundação Sistema ES tadual de Anālise de Dados (1983) dos mịgrantes sazonais da região de Ribeirão Preto, $63 \%$ procedem de outros Estado, sendo $52,9 \%$ de Minas Gerais, $5,9 \%$ do Paranā e 4,2\% dos demais Estados da Federação (citado por GEBARA et alii, 193.8).

Não se dispõe de uma série de dados sobre o nümeró de migrantes de outros estados, que vêm para trabalhar, principalmente na colheita de cana-de-açūcar. Acredita-se que esta seja uma variāa ve 1 importante a ser considerada na equação de oferta: "as migrações sazonais desempenham atualmente, um papel importante no sentido de $\underline{e}$ vitar um crescimento ainda maior dos salários rurais nos momentos de "pico" da atividade agrícola numa dada região. Por exemplo, se os vo lantes não pudessem se deslocar, ném pudessem alternar empregos r $\underline{u}$ rais e urbanos durante o ano, o seu salärio por dia teria que cres cer a medida que trabalhassem menos dias por ano, considerando-se o seu cus to de reprodução por ano como dado. Por isso, concomi tantemen te com o crescimento da sazonalidade do trabalho na agricultura paulis ta observa-se um aumento dos deslocamentos populacionais tanto dentro do Estado de São Paulo, como de regiões vizinhas (GRAZIANo DA SILvA, 1980). 
Estima-se que cerca de $50 \%$ do movimento populacional em São Paulo origine-se dentro da pröprio estado, sendo o restante prọ veniente de estados vizinhos (Paranā, Mato Grosso, Rio de Janeiro e Minas Gerais) e de alguns estados do Nordeste (destacando se a Bahia) (JORDAO NETTO, coord., 1976).

Com relação à variāvel salàrio alternativo, o coefi ciente de - 0,38, indica que um aumento de $1 \%$ no salärio mínimo vi gente no Estado de São Paulo, poderia acarretar um decréscimo da or dem de $0,38 \%$ na quantidade ofertada de mão-de-obra volante. Embora se observe atração do volante pelo salārio mínimo, a elevada mobilidade do trabatho não qualificado, evidenciado em períodos anteriores, pare ce ter diminuido. Salienta-se aqui, que apesar da sazonalidade da mão-de-obra volante, mui tos trabalhadores conseguem empregar-se nas fazendas quase que o ano todo, ocasionando menos necessidade de alter nāncia de empregos.

0 coeficiente da variāvel emprego nos setores indus trial e da construção civi l não apresentou significāncia estatística. Porēm, julgou-se importante a inclusão desta variāvel no modelo de $\underline{0}$ ferta uma vez que se constatou em diversos estudos a alternāncia do trabatho rural e urbano.

0 sinal dessa variāvel sugere que condições favorāveis em termos de emprego na industria e na construção civil acarretariam diminuição da oferta de trabatho volante.

De forma semethante ao ocorrido na equação de demanda , foram significativos os coeficientes de $T_{1}$ e $T_{2}$, indicando desta forma, diferentes tendéncias entre os períodos novembro de 1974 a junho de 1979 e setembro de 1979 a abril de 1981. 
4. CONCLUSOES

Dos resultados obtidos no presente estúdo è possível re tirar algumas conclusões. Observou-se relação de substituição entre o trabalho volante e motomecanização na agricultura paulista. Embora, o emprego de volantes seja représentativo, com destaque para as épocas de colheita, não se deve esquecer que jā se encontra motomecanizada parte da ārea colhida das principais culturas anuais. No caso do algodão e da cana-de-açūcar, culturas que empregam expressivamente a mão-de-obra volante, jā existem colhedeiras,ainda que mal adaptadas.

Alerta-se, desta forma, para que a intensificação do $\underline{u}$ so de tração motomecānica na agricultura, incentivada por meio de planos especiais para aquisição de mäquinas, deva levar em con ta os reflexos no mercado de trabalho rural. 0 processo de motomecani zação seria desejāvel em ciclos de expansão econōmica, quanto parte dos trabalhadores, que se encontram em condições de trabalho menos fa vorāveis no setor agrícola, poderiam ser absorvidos por outros setores da economia ou ainda permanecer na agricultura mas com outra relação de trabaiho. Jā em situações econômicas desfavorāveis como as mais recen tes, esse processo resultaria em desemprego.

Os resultados obtidos evidenciam, tambēm, a existência complementariedade entre o trabalho volante e o residente, uma vez que ca be à mão-de-obra residente a realização das tarefas diärias nas proprie dades, sendo a participação do volante mais representativa nas ativida des eventuais, para as quais não seria econōmico manter um grande nūme 
ro de trabalhadores residentes.

observou-se que as polîticas de preços agrícolas favorá veis ao agricultor apresentam resultados positivos para o emprego agrí cola. No período estudado, a relação entre preços recebidos e preços pagos foi favorável aos agricultores paulistas de 1975/76 a 1978/79, tornando-se desfavorāvel no final da década de setenta e em meados dos anos oitenta. Recupera-se em 1986/87, quando novas medidas económicas foram adotadas no país.

Outro aspecto a ser destacado seria o resultado obtido de relativa inelasticidade salärio da demanda de volante, a curto pra zo, ou seja, acréscimos ou decréscimos no salärio reat não estariam a fetando a quantidade demandada. Este resultado aponta a importāncia do trabalho volante nas diversas operações agrícolas.

Constatou-se sensibilidade dessa categoria de trabalhador às variações tanto no salärio minnimo (variāvel utilizada para represen tar o salärio alternativo), quanto na diāria paga aos volantes. Notase, porém, que os bōias-frias mostram maior sensibilidade aos salārios pagos à prōpria categoria. Embora seja de conhecimento que os volantes estão sujeitos a piores condições de trabalho quando comparados à ou tros trabalhadores, as transformações ocorridas na composição da pro dução agrícola relativas ao crescimento da ārea cultivada com produtos que empregam mão-de-obra volante, proporcionaram maiores oportunidades de emprego no setor rural.

Esse fato tem levado, segundo pesquisas recentes, $\bar{a}$ for mação de turmas de trabalho que se empregam nas propriedades durante boa parte do ano, e nos períodos de colheita obtem uma renda maior. Is 
so leva a crer que a renda mēdia anual e a segurança no emprego te nham se tornado mais estāveis, em comparação a perĩodos anteriores.

Atualmente, o trabaiho volante representa cerca de $30,0 \%$ da força de trabalho empregada na agricultura paulista.

Justifica-se, portanto, a necessidade de novos estudos que possam detectar outras variāveis relevantes para que se conheça melhor o mercado de mão-de-obra volante. Os resultados es tatísticos discutidos nesta pesquisa referem-se a um modelo estātico, mas pretende-se dar continuidade ao trabalho efetuando-se também o ajustamento de um modelo dināmico.

Com relação as estatísticas existentes sobre mão-de-o bra, acredita-se que o aprimoramento e a continuidade das sēries de da dos sejam fatores relevantes para a elaboração de futuras pesquisas no campo de emprego agrícola. 


\section{REFERENNCIAS BIBLIOGRAFICAS}

ANUARIO ESTATISTICO DO BRASIL. Rio de Janeiro, FIBGE, 1974-87.

BACCARIN, J.G. 1985 Trabalhadores rurais volantes da região de Jaboticabal: crescimento, características e aspectos organizacionais.

Piracicaba, ESALQ/USP. 161 p. (Tese - Mestrado).

BARROS, G.S.C. 1980 Investimento em tratores agricolas no Brasil. Pi racicaba, ESALQ/USP, 135 p. (Tese - Livre Docente).

BATISTA, I.S. 1976 A demanda de tratores agrícolas na região CentroSul do Brasil. Viçosa, Universidade Federal de Viçosa, 84 p. (TeseMestrado)

BOMB0, N.; BRUNELI, R. 1966 Estudo da condição de safreiro: aborda gem inicial de um problema societārio e institucional. Piracicaba, Faculdade de Serviço Social. 126 p. (datilografado).

BRANDT, V.C. 1977 Do colono ao bōia-fria: transformações na agricultú ra e constituição do mercado de trabalho na Alta Sorocabana de Assis. Estudo Cebrap, São Paulo. 1937 -92:

CAMARGO, M.N. 1988 Amostra para previsão e estimativas de safras agríColas do Estado de São Paulo, em vigor em junho de 1981. Săo Paulo, Secretaria de Agricultura e Abastecimento, IEA (no pre10). 
CAilARGO FILHO, W.P.C. et alii 1989. Estatísticas da produção agropecuảria no Estado de São Paulo. São Paulo, Secretaria da Agricultura, Instituto de Economia Agrícola (no prelo).

CAMPOS, H.; PIVA, L.H.O. 1974. Dimensionamento de amostra para estimati va e previsão de safras no Estado de São Paulo. Agricultura em São Pauto, SP, 21 (3): 65-88.

CANABRAVA, A.P.; MENDES, M.T. 1938. A região de Piracicaba. Revista do Arquivo Municipal - São Paulo, 45: 275-328.

D'INCAO e MELLO, M.C. 1975. O "Bōia-Fria": acumulação e miséria. Petrō polis, Vozes; Presidente Prudente, Faculdade de Filosofia, Ciēncias e Letras. p. 40-41.

ETTORI, O. J.T. 1961. Mão-de-obra na agricultura de São Paulo: catego rias - remuneração - legis lação. Agricultura em São Paulo, SP, 8 (12): 13-39, dez .

FERGUSON, C.E. 1976. Microeconomia. Rio de Janeiro ed. Forense - Uni versitāria. $616 \mathrm{p}$.

GARCIA, A. E.B. 1986. Ocupação da mão-de-obra na agricultura do Estado de São Paulo na década de setenta. São Pauto, Secretaria de Agricul tura e Abastecimento, IEA. 52 p. (Relatório de Pesquisa, 01/86).

GASQUES, J.G. 1975. Oferta e demanda de mão-de-obra volante no Estado de São Pau10. Piracicaba, ESALQ/USP, 63 p. (Tese - Mestrado). 
GATTI, E. U. 1984 A política agrícola e a composição da produção e utilização de mão-de-obra na agricultura paulista na década de setenta. São Paulo, FEA/USP, 181 p. (Tese - Mestrado).

GEBARA, J.J.; BACCARIN, J.G.; BORBA, M.M.Z. 1988 Fatores condicionan tes e formas de migração sazonal: o caso da migração do vale do Je quitinhonha (MG) para a região canavieira de Ribeirão Preto (SP) Revista de Economia Rural, Brasilia, 26 (1): jan./mar.

GHILARDI, A.A. 1986 Transformações na agricultura paulista na década de setenta, ao nivel de tamanho de propriedade São Paulo, FEA/USP, $168 \mathrm{p}$. (Tese - Mestrado).

GHILARDI, A.A.; BEMELMANS, P.F. 1986. Desempenho de propriedades agropecuārias paulistas, 1970 a 1983: um estudo de caso. São Paulo, Secretaria de Agricultura e Abastecimento, IEA. 56 p. (Relatōrio de Pesquisa, 21/86).

GONZALES, E.N.; BASTOS, M.I. 1975. O trabaitho volante na agricultura brasileira. In. Reunião da Sociedade Brasileira de Economia Rural, 13, Curitiba 1975, SOBER. p. 34.

GRAZIANO DA SILVA, J.F.;FREITAS, G..1976. Os volantes na zona de Avarē e Cerqueira César. Botucatu, II Reunião Nacional de Mão-de-Obra Yo lantes na Agricultura.

GRAZIANO DA SILVA, J.F. 1980. Progresso técnico e relações de trabalho na agricultura paulista. Campinas, IFCH/UilICAMP, $294 \mathrm{p}$. (Tese - Dou torado). 
GRAZIANO DA SILVA,J,F,1982. 0 "bōia-fria" entre aspas e com os pingos nos is. In: Departamento de Economia Rural - FCA de Botucatu, Org. A Mão-de-Obra Volante na Agricultura, São Paulo, CNPq/UNESP/POLIS, p. $137-177$.

HOFFMANN, R.; VIEIRA, S. 1977. Anālise de regressāo: uma introdução à econometria. São Paulo, HUCITEC/EDUSP, $339 \mathrm{p}$.

IEA, Instituto de Economia Agrīcola Informações Econōmicas. São Paulo, SP, värios exemplares.

IEA, Instituto de Economia Agrīcola 1977. Prognōstico 77/78. São Paulo, SP, Secretaria da Agricultura v,6.

IEA, Instituto de Economia Agrícola 1980. Prognóstico 80/81. São Pau 10, SP, Secretaria da Agricultura v. 9.

JORDAO NETTO, A. coord. 1976. Movimentos populacionais no interior do Estado de São Paulo, Secretaria da Promoção Social. 76 p. (Documento Técnico, 5).

KAGEYAMA, A. et alii. 1981. Evolução técnica e emprego a nîvel de cultu ras: parte B, relatōrio final. Campinas, UNICAMP. 139 p. (Tex to para discussão, 7). 
MARSHALL, M.; PERES, M.C.R.C. 0 método de minnimos quadrados de dois estāgios: seus fundamentos e aplicações na estimação da demanda e da oferta de ovos no Estado de São Pau1o. ESALQ/USP. Departamento de Ciências Sociais Aplicadas, (Série Pesquisa nọ 32).

NA DISPUTĩ por mäo-de-obra, cidade bate campo.. Folha de São Paulo , 04 de novembro de 1986. Suplemento Agrofolha, p. 8.

NEGRI NETTO, A. et alii. 1989. Custo e beneficio social de previsões e estimativas de produção agrícola: o valor da informação. São Pau 10, Secretaria da Agricultua, Instituto de Economia Agrícola, IEA (no pre 10).

NOJIMOTO, T. 1987. Obstáculos à mecanização da agricultura brasileira São Pauto, FEA/USP 345 p. (Tese - Doutorado).

PAIVA, R. M.; SCHATTAN. S.; FREITAS, C.T. 1973. 0. setor agricola do Brasil: comportamento econömico, problemas e. possibilidades. São Paulo, Secretaria da Agricutura, $465 \mathrm{p}$.

PESQUISA NACIONAL POR AMOSTRA DE DOMICILIOS Rio de Janeiro. IBGE $1975-86$.

PITERI, A. D. 1964. O estatuto do trabaihador rural: problemas de aplí cação e provaveis consequēncias sócio-econōmicas. Agricultura em São Pauto, SP, 11 (1/2): 1-16 jan./fev. 
QUEDA, O.; SILVA, J.G.; PINHEIRO, F.A. 1977. Contribuição ao Estudo do trabalho volante no Estado de São Paulo. Piracicaba, ESALQ/USP 129 p.

SANDERS, J.H. 1973. Mechanization and employment in brasilian agriculture, 19501971. s.1.p. 262 p. Minnesota University, (Tese PhD).

SAYLOR, R.G. 1974. Procura e oferta de mão-de-obra agrícola no Esta do de São Paulo. Agricultura em São Paulo, 21 (3): 129-146.

SCHUH, G.E. 1962. An econometric investigation of the market for hired labor in agriculture. Journal of Farm Economics, 44 (2): 307-321, may .

VASSIMON, S. G. 1966. Estudo preliminar sobre o problema de mão-de-obra na agricultura no Estado de São Paulo. s.n.t. 39 p. (Datilogra fado)

VICENTE, M. C.M. 1985. A evolução do uso de mão-de-obra e da mecanização em cult turas do Estado de São Paulo. São Paulo, Secretaria de Agricultura e Abastecimento, IEA. 22.p. (Relatōrio de Pesquisa, $08 / 85)$.

VICENTE, M.C.M.; BAPTISTELLA, C.S.L. 1986. Mão-de-obra na agricultura paulista, 1985. Informações Econōmicas, São Paulo, 16 (9): 29-38; set. 
'VICENTE, M.C.M; BAPTISTELLA, C.S.L. 1987. Trabalho volante na agricultura paulista, 1975 a 1986 . São Paulo, Secretaria de Agricultura e Abastecimento, IEA.31 p: (Relatōrio de Pesquisa, 16/87).

VICEiTTE, M.C.M.et alii 1988 . Estimativas de mão-de-obra e demografia no setor agrícola paulista: 1986/87. Informações Económicas, São Paulo, 16 (8): 29-37, ago. 
75.

$$
\text { A PENDICE }
$$


Taoela A.1. - In rororacôes Básicas.

Sal. minimo

Ho volantes

Periodo enpregados

$(+15$ anos)
Salário de vigente no Est

Săo Paulo de trocas

volantes
(Cz\$ de 67/dia)(C2\$ de 87/dia) Base 1966=109 (1)
Populatăo Pessoal ocup. Area trabalhada trabalhadora ind. e constr. con tráăo woresicente civil, Est. SF. todecânica na no imóvel (até 2 sal.rin.) capina $e$ co$1974 / 75=160$ 1974/75=190(2) lheita (3)

\begin{tabular}{|c|c|c|c|c|c|c|c|}
\hline now/74 & 266.369 & 170,93 & 141,70 & 89,78 & 100,0 & 190,0 & 19,7 \\
\hline fev/75 & 286.167 & 170,53 & 136,83 & 89,78 & 100,0 & 106,0 & 19,7 \\
\hline $\mathrm{abr} / 7 \mathrm{~s}$ & 390.946 & 230,11 & 132,33 & 89,78 & 100,0 & 100,9 & 19,7 \\
\hline jun $/ 75$ & 270.753 & 175,28 & 173,63 & 89,78 & 100,0 & 100,0 & 19,7 \\
\hline now $/ 75$ & 207.667 & 166,40 & 154,80 & 193,52 & 99,0 & 100,0 & 24,1 \\
\hline ลอง $/ 76$ & 211.238 & 173,31 & 135,64 & 103,52 & 99,0 & 192,0 & 24,1 \\
\hline jun $/ 76$ & 283.450 & 179,30 & 178,12 & 193,52 & 99,0 & 102,0 & 24,1 \\
\hline $\mathrm{set} / 76$ & 293.114 & 163,77 & 159,37 & 103,52 & 99,0 & 102,0 & 24,1 \\
\hline nov/7b & 320.537 & 171,70 & 152,79 & 134,41 & 100,8 & 102,0 & 26.0 \\
\hline Sev/77 & 411.344 & 181,50 & 144,30 & 134,41 & 100,8 & 105,7 & 28,0 \\
\hline $\mathrm{abr} / 77$ & 458.196 & 194,21 & 133,12 & 134,41 & 100,8 & 165,7 & 20,0 \\
\hline $\mathrm{jun} / 77$ & 378.485 & 215,39 & 175,46 & 134,41 & 100,8 & 105,7 & 26,6 \\
\hline set $/ 77$ & 325.455 & 273,61 & 166,89 & 134,41 & 199,8 & 165,7 & 20,9 \\
\hline nov $/ 77$. & 366.564 & 176,09 & 158,23 & 138,25 & 105,9 & 105,7 & 30,8 \\
\hline fEv $/ 78$ & 396.494 & 199,26 & 150,45 & 139,25 & 105,9 & 117,6 & 30,8 \\
\hline $\mathrm{abr} / 78$ & $41 \bar{B} .360$ & 184,05 & 140,96 & 138,25 & 165,9 & 117,6 & 30,8 \\
\hline jun $/ 78$ & 483.783 & 198,55 & 180,40 & 138,25 & 165,9 & 117,6 & 30,8 \\
\hline set $/ 78$ & 246.140 & 217,61 & 166,56 & 138,25 & 105,9 & 117,6 & 30,8 \\
\hline nov $/ 78$ & 363.076 & 146,44 & 157,58 & 112,90 & 100,0 & 117,6 & 33,2 \\
\hline fEv/79 & 393.537 & 186,00 & 149,41 & 112,90 & 160,8 & 106,7 & 33,2 \\
\hline abr $/ 79$ & 367.414 & 180,75 & 136,09 & 112,90 & 190,8 & 106,7 & 33,2 \\
\hline jun $/ 79$ & 527.474 & 202,07 & 184,63 & 112,90 & 100,8 & 106,7 & 33,2 \\
\hline set $/ 79$ & 289.689 & 170,59 & 155,23 & 112,90 & 100,8 & 106,7 & 33,2 \\
\hline now $/ 79$ & 339.524 & 167,29 & 176,71 & 101,46 & 97,0 & 106,7 & 35,1 \\
\hline fev/80 & 302.649 & 164,69 & 159,89 & 101,46 & 97,9 & 109,7 & 35,1 \\
\hline aor $/ 80$ & 279.447 & 177,52 & 141,90 & 191,46 & 97,0 & 109,7 & 35,1 \\
\hline jun $/ 80$ & 299.771 & 180,24 & 171,28 & 161,46 & 97,6 & 109,7 & 35,1 \\
\hline $\operatorname{set} / 80$ & 240.974 & 151,25 & 140,29 & 101,46 & 77,0 & 199,7 & 35,1 \\
\hline now/60 & 248.949 & 161,84 & 163,70 & 78,35 & 85,9 & 109,7 & 37,2 \\
\hline $\mathrm{abr} / 8 \mathrm{i}$ & 275.659 & 179,58 & 281,80 & 98,35 & 85,9 & 100,0 & 37,2 \\
\hline$f E v / 85$ & 291.691 & 124,43 & 199,66 & 96,91 & 96,6 & 113,3 & 49,2 \\
\hline jun/85 & 343.789 & 174,46 & 138,04 & 96,91 & 96,6 & 113,3 & 43,2 \\
\hline set $/ 85$ & 252.130 & 138,94 & 191,87 & 96,91 & 96,6 & 113,3 & 43,2 \\
\hline now $/ 85$ & 207.276 & 132,31 & 137,94 & 98,06 & 98,7 & 113,3 & $42, \hat{C}$ \\
\hline fev/86 & 342.392 & 106,65 & 86,70 & 98,06 & 98,7 & 90,9 & 42,2 \\
\hline $\mathrm{abr} / 86$ & 404.177 & 156,20 & 144,88 & 98,06 & 98,7 & 98,9 & $4 \hat{\varepsilon}, \hat{2}$ \\
\hline jun $/ 86$ & 329.993 & 163,20 & 113,90 & 98,06 & 98,7 & 98,9 & $4 \mathrm{E}, 2$ \\
\hline set $/ 86$ & 372.660 & 204,28 & 110,50 & 98,00 & 98,7 & 98,9 & 42,2 \\
\hline nov $/ 86$ & 370.066 & 208,52 & 110,50 & 120,16 & 105,2 & 98,9 & 48,5 \\
\hline$\{8 v / 87$ & 358.569 & 223,01 & 112,32 & 120,16 & 105,2 & 100,0 & 48,5 \\
\hline abr $/ 87$ & 434.367 & 183,02 & 107,27 & 120,16 & 105,2 & 100,0 & 48,5 \\
\hline jun/87 & 423.471 & 159,01 & 90,90 & 120,16 & 165,2 & 100,0 & 48,5 \\
\hline set $/ 87$ & 411.599 & 148,37 & 87,61 & 120,16 & 165,2 & 100,0 & 48,5 \\
\hline
\end{tabular}

(1) Foi utilizado como deflator o indice "2" da Conjuntura Econômica.

(2) Os anos de 1974, 1975 E 1987 foran esti imados por regressăo.

(3) Os anos de $1976 / 77,1977 / 78$ e $1978 / 79$ for an estimados por regressăo.

Fonte: Iados básicos do Inst. de Economia Agricola (IEA) e da Fundacăo Inst. Brasileiro de Geograłia e Estatistica (IBGE). 